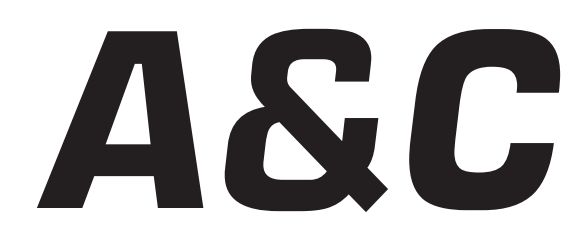

Revista de Direito Administrativo \& Constitucional

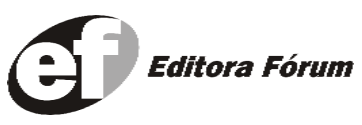

A\&C R. de Dir. Administrativo e Constitucional, Belo Horizonte, ano 5, n. 22, p. 1-253, out./dez. 2005 


\section{A\&C REVISTA DE DIREITO ADMINISTRATIVO E CONSTITUCIONAL}

\section{IPDA}

Instituto Paranaense

de Direito Administrativo

Direção Geral

Romeu Felipe Bacellar Filho

Direção Editorial

Paulo Roberto Ferreira Motta

Direção Executiva

Emerson Gabardo

Conselho de Redação

Edgar Chiuratto Guimarães

Adriana da Costa Ricardo Schier

Célio Heitor Guimarães

Conselho Editorial

Adilson Abreu Dallari

Alice Gonzáles Borges

Carlos Ari Sundfeld

Carlos Ayres Britto

Carlos Delpiazzo

Cármen Lúcia Antunes Rocha

Celso Antônio Bandeira de Mello

Clèmerson Merlin Clève

Clóvis Beznos

Enrique Silva Cimma

Eros Roberto Grau

Fabrício Motta

Guilhermo Andrés Muñoz (in memoriam)

Jaime Rodríguez-Arana Muñoz

Jorge Luís Salomoni
José Carlos Abraão
José Eduardo Martins Cardoso

José Luís Said

José Mario Serrate Paz

Juan Pablo Cajarville Peruffo

Juarez Freitas

Julio Rodolfo Comadira

Luís Enrique Chase Plate

Lúcia Valle Figueiredo

Manoel de Oliveira Franco Sobrinho

(in memoriam)

Marçal Justen Filho

Marcelo Figueiredo

Márcio Cammarosano

Maria Cristina Cesar de Oliveira
Nelson Figueiredo

Odilon Borges Junior

Pascual Caiella

Paulo Eduardo Garrido Modesto

Paulo Henrique Blasi

Paulo Neves de Carvalho (in memoriam)

Paulo Ricardo Schier

Pedro Paulo de Almeida Dutra

Regina Maria Macedo Nery Ferrari

Rogério Gesta Leal

Rolando Pantoja Bauzá

Sérgio Ferraz

Valmir Pontes Filho

Yara Stropa

Weida Zancaner

\footnotetext{
A246 A\&C Revista de Direito Administrativo e Constitucional. ano 3, n. 11, jan./mar. 2003. Belo Horizonte: Fórum, 2003.

Trimestral

ano 1, n.1, 1999 até ano 2, n.10, 2002 publicada pela Editora Juruá em Curitiba

ISSN: 1516-3210

1. Direito Administrativo. 2. Direito Constitucional. I. Fórum.
}

CDD: 342 CDU: 33.342

(c) Editora Fórum Ltda. 2005

Todos os direitos reservados. É proibida a reprodução total ou parcial, de qualquer forma ou por qualquer meio eletrônico ou mecânico, inclusive através de processos xerográficos, de fotocópias ou de gravação, sem permissão por escrito do possuidor dos direitos de cópias (Lei $n^{\circ}$ 9.610, de 19.02.1998).

Editora Fórum Ltda

Av. Afonso Pena, 2770 - 15\%16ªndar - Funcionários

CEP 30130-007 - Belo Horizonte/MG - Brasil

Tel.: 08007043737

Internet: www.editoraforum.com.br

e-mail: editoraforum@editoraforum.com.br
Editor responsável: Luís Cláudio Rodrigues Ferreira Projeto gráfico e diagramação: Luis Alberto Pimenta Revisora: Olga M. A. Sousa

Pesquisa jurídica: Fátima Ribeiro - OAB/MG 74868

Bibliotecária: Nilcéia Lage de Medeiros

CRB 1545/MG 6a região

Os conceitos e opiniões expressas nos trabalhos assinados são de responsabilidade exclusiva de seus autores.

Impressa no Brasil / Printed in Brazil

Distribuída em todo Território Nacional 


\title{
Sanção Administrativa e o Princípio da Culpabilidade
}

\author{
Rafael Munhoz de Mello \\ Mestre em Direito Administrativo pela PUC/SP. Advogado em Curitiba
}

Sumário: Introdução - 1 Sanção administrativa - 1.1 Conceito - 1.2 Sanção administrativa retributiva e sanção administrativa ressarcitória - 2 O princípio da proporcionalidade e o direito administrativo sancionador - 2.1 Estado de Direito e proporcionalidade - 2.2 Proporcionalidade em sentido estrito e sanção administrativa - $\mathbf{2 . 3}$ Vedação às sanções permanentes $\mathbf{- 3} \mathrm{O}$ princípio da culpabilidade - 3.1 Proporcionalidade e culpabilidade: exigência de dolo ou culpa - 3.2 Insuficiência da mera voluntariedade - 3.3 Pessoalidade e intransmissibilidade da sanção administrativa - $3.4 \mathrm{O}$ erro no direito administrativo sancionador. O erro de tipo - $\mathbf{3 . 5}$ O erro de proibição Conclusão - Referências bibliográficas

\section{Introdução}

Muito embora seja também uma manifestação do poder punitivo estatal, ao lado da sanção penal, a sanção administrativa é tratada no direito brasileiro como se fosse medida punitiva de importância secundária, incapaz de atingir de modo grave a esfera jurídica dos particulares. Com efeito, nota-se na doutrina e na jurisprudência pátria certa resistência à aplicação, no direito administrativo sancionador, de princípios que há mais de dois séculos são utilizados no direito penal. Em certos aspectos, revela-se muito atual no Brasil a expressão que García de Enterría utilizou para qualificar o direito administrativo sancionador espanhol na década de 70: pré-beccariano. ${ }^{1}$

Não se trata de aplicar acriteriosamente os princípios do direito penal no campo do direito administrativo sancionador, mas sim de reconhecer que ambos os ramos jurídicos têm um núcleo comum, formado por princípios que derivam diretamente da opção constitucional por um Estado de Direito. ${ }^{2}$ Tais princípios devem ser observados em qualquer manifestação do poder punitivo estatal, seja ele exercido pelo Poder

\footnotetext{
El Problema Jurídico de las Sanciones Administrativas, p. 10.

2 "Cuando se declara que las mismas garantías observables en la aplicación de las penas se han de respetar cuando se trata de imponer una sanción administrativa, no se hace en realidad referencia a todos y cada uno de los principios o reglas reunidos en la Parte General (del Derecho Penal), sino a aquellos a los que el derecho penal debe someterse para satisfacer los postulados del Estado de Derecho, que son principios derivados de los declarados en la Constitución como fundamentales" (OLIVARES, Quintero. La Autotutela, los Limites al Poder Sancionador de la Administración Pública y los Principios Inspiradores del Derecho Penal, p. 262).
}

A \& C R. de Dir. Administrativo e Constitucional, Belo Horizonte, ano 5, n. 22, p. 25-57, out./dez. 2005 
Judiciário, através da imposição de sanções penais, seja ele exercido pela Administração Pública, através da imposição de sanções administrativas. Afinal, nas palavras de Alberto Xavier, “o mesmo Estado não pode aceitar respeitáveis princípios de civilização moderna, comportar-se como Estado civilizado num determinado capítulo e rasgar os valores da civilização noutro capítulo". ${ }^{3}$

Dito em outras palavras, é o mesmo Estado que impõe a sanção administrativa e a sanção penal, muito embora no exercício de funções estatais distintas, o que confere regimes jurídicos diversos a um caso e ao outro. Mas a diversidade de regime jurídico não significa que as garantias dos particulares possam ser ignoradas nos casos em que é a Administração Pública e não o Judiciário que impõe a sanção.

Enfim, há um regime jurídico punitivo que deve ser observado em toda manifestação do poder punitivo estatal. ${ }^{4}$ Pretende-se demonstrar no presente estudo que o princípio da culpabilidade integra tal regime jurídico, ao contrário do que sustentam autorizadas vozes da doutrina pátria.

\section{Sanção administrativa}

\subsection{Conceito}

Pode-se definir sanção jurídica como a conseqüência negativa atribuída à inobservância de um comportamento prescrito pela norma jurídica, que deve ser imposta pelos órgãos competentes, se necessário com a utilização de meios coercitivos. Ao estabelecer a sanção jurídica, atribui o legislador uma conseqüência negativa à prática do comportamento ilícito, pretendendo com isto incentivar a observância das condutas prescritas. Em tal sentido, pode-se afirmar que a sanção é "una misura indiretta di cui il legislatore si avvale per ottenere l'osservanza della legge", na lição de Giuseppe Berliri. ${ }^{5}$

A sanção administrativa é uma sanção jurídica. Como tal, a ela se aplica o conceito acima. Mas há peculiaridades que identificam a sanção

\footnotetext{
VI Curso de Especialização em Direito Tributário, p. 736.

4 "Constitui exigência constitucional que toda vez que se configure situação em que o particular esteja diante do estado no exercício do seu direito de punir (castigar), incide automática e imediatamente o chamado regime jurídico punitivo, assim designado o conjunto de preceitos constitucionais e legais que estabelece limites procedimentais, processuais e substanciais à ação do Estado, nesta matéria (exercício do jus puniendi)" (ATALIBA, Geraldo. Imposto de Renda - Multa Punitiva, p. 550).

${ }^{5}$ Sanzioni Amministrative e Principi Costituzionali della Potestá Punitiva Penale, p. 285. Note-se que em \} sentido lato sanção pode ser entendida não só como conseqüência negativa atribuída ao descumprimento de um comportamento prescrito por norma, mas também como conseqüência positiva atribuída pelo
} 
administrativa entre as demais sanções jurídicas. A principal peculiaridade diz respeito ao sujeito competente para sua imposição, a saber, a própria Administração Pública. Trata-se de elemento decisivo para identificá-la. Se a medida punitiva não é imposta pela Administração Pública de sanção administrativa não se trata. Logo, é o elemento subjetivo que permite diferenciar a sanção administrativa da sanção penal: "o que as aparta", ensina Celso Antônio Bandeira de Mello, "é única e exclusivamente a autoridade competente para impor a sanção". ${ }^{6}$

Trata-se de posição pacífica na doutrina nacional e estrangeira. Para Eduardo García de Enterría e Tomás-Ramón Fernándes, a sanção administrativa distingue-se da penal "por un dato formal, la autoridad que las impone: aquéllas, la Administración, éstas, los Tribunales penales". ${ }^{7}$ Na Itália, Guido Zanobini foi o precursor da idéia de que "sono pene amministrative e non sanzioni penali tutte quelle la cui applicazione è dalla legge riservata all'autorità amministrativa". ${ }^{8}$ No mesmo sentido, Mireille Delmas-Marty e Catherine Teitgen-Colly ensinam, a respeito do direito administrativo francês, que "la sanction administrative s'identifie d'abord par son auteur: elle émane d'une autorité administrative".${ }^{9}$ E no Brasil Régis Fernandes de Oliveira, em sua pioneira obra a respeito das sanções administrativas, anota que "crime e contravenção são julgados por órgão jurisdicional, enquanto a infração [administrativa] por órgão administrativo". ${ }^{10}$

Portanto, o traço que identifica a sanção administrativa é formal,

cumprimento de tal comportamento. Tanto num caso como noutro há uma medida cujo objetivo é "ottenere l'osservanza della legge". Mas a expressão é usualmente utilizada para se referir à primeira hipótese, não à segunda, e em tal sentido é empregada no presente trabalho. Sobre o tema, veja-se o seguinte trecho de Kelsen: "A ordem social (...) pode estatuir uma determinada conduta humana e, simultaneamente, ligar a esta conduta a concessão de uma vantagem, de um prémio, ou ligar à conduta oposta uma desvantagem, uma pena (no sentido mais amplo da palavra). O princípio, que conduz a reagir a uma determinada conduta com um prémio ou uma pena é o princípio retributivo. O prémio e o castigo podem compreender-se no conceito de sanção. No entanto, usualmente, designa-se por sanção somente a pena, isto é, um mal — a privação de certos bens como a vida, a saúde, a liberdade, a honra, valores económicos - a aplicar como conseqüência de uma determinada conduta, mas já não o prémio ou a recompensa" (Teoria Pura do Direito, p. 49).

6 Curso de Direito Administrativo, p. 743.

7 Curso de Derecho Administrativo, v. II, p. 159. Ver ainda, no direito espanhol, NIETO, Alejandro. Derecho Administrativo Sancionador, p. 182; SUAY RINCÓN, José. Sanciones Administrativas, p. 55; CARRETERO PÉREZ; Adolfo; CARRETERO SANCHEZ, Adolfo. Derecho Administrativo Sancionador, p. 101; MARTÍNRETORTILLO BAQUER, Lorenzo. Multas Administrativas, p. 11-12; GARRIDO FALLA, Fernando. Tratado de Derecho Administrativo, v. II, p. 162.

8 Le Sanzioni Amministrative, p. 40. No direito italiano, ver ALESSI, Renato. Responsabilità Amministrativa, p. 618, bem como Principi di Diritto Amministrativo, v. I, p. 283; SINISCALCO, Marco. Depenalizzazione e Garanzia, p. 140-141; ROSINI, Emilio. Le Sanzioni Amministrative, p. 26.

9 Punir sans Juger?, p. 38. No mesmo sentido, na França: MODERNE, Franck. Sanctions Administratives et Justice Constitutionnelle, p. 133; DE LAUBADĖRE, André; VENEZIA, Jean-Claude; GAUDEMET, Yves. Traité de Droit Administratif, p. 708; Les Pouvoirs de l'administration dans le Domaine des Sanctions, p. 35.

${ }^{10}$ Infrações e Sanções Administrativas, p. 32. No mesmo sentido, Hugo de Brito Machado ensina: "o único critério válido, em nosso Direito positivo, para distinguirmos as sanções penais das sanções administrativas, é o da competência para a correspondente aplicação" (Teoria das Sanções Tributárias, p. 164). Em sentido contrário, ver OSÓRIO, Fábio Medina. Direito Administrativo Sancionador, p. 62. 
já que leva em conta o regime jurídico da atividade sancionadora. É que ao atribuir à Administração Pública competência para impor a sanção administrativa, a lei determina que tal atividade sancionadora seja praticada no exercício da função administrativa, que se diferencia das demais funções estatais, inclusive da jurisdicional, por força do seu regime jurídico. Os atos praticados no exercício da função administrativa têm um regime jurídico próprio, distinto dos atos praticados no exercício das funções jurisdicional e legislativa. ${ }^{11}$ Ainda que materialmente sejam idênticas as atividades - o julgamento proferido num processo judicial e o proferido num processo administrativo, p. ex. —, do ponto de vista jurídico há diferença entre a manifestação da função administrativa e a manifestação das demais funções estatais.

De conseqüência, sanção administrativa pode ser conceituada como a medida aflitiva imposta pela Administração Pública em função da prática de um comportamento ilícito. ${ }^{12}$

\subsection{Sanção administrativa retributiva e sanção administrativa ressarcitória}

As sanções administrativas podem ser classificadas de acordo com os mais variados critérios. ${ }^{13}$ Parece relevante destacar a classificação que separa as sanções administrativas em duas categorias: i) sanções que consistem em medidas aflitivas de caráter retributivo e ii) sanções que consistem em medidas aflitivas de caráter ressarcitório. Tanto num caso como noutro há uma sanção jurídica imposta pela Administração Pública, no exercício da função administrativa. Portanto, ambas são sanção administrativa. Contudo, o regime de uma espécie e outra é distinto, como será visto logo adiante.

\footnotetext{
11 "Une fonction est alors un ensemble de missions exercées selon un même régime" (BÉNOIT, Francis-Paul. Droit Administratif Français, p. 40).

${ }^{12} \mathrm{O}$ conceito proposto segue a linha adotada por Eduardo García de Enterría e Tomás-Ramón Fernández, que conceituam sanção administrativa como "un mal infligido por la Administración a un administrado como consecuencia de una conducta ilegal" (Curso de Derecho Administrativo, v. II, p. 159). Em sentido semelhante é o conceito de Suay Rincón, para quem sanção administrativa é "cualquier mal infringido por la Administración a un administrado como consecuencia de una conducta ilegal a resultas de un procedimiento administrativo y con una finalidad puramente repressora" (Sanciones Administrativas, p. 55). No conceito ora proposto não se faz referência à necessidade de prévio processo administrativo, como o faz Suay Rincón, em função de não se tratar de característica própria das sanções administrativas, já que por força do princípio constitucional do devido processo legal todo ato estatal que atinja a esfera jurídica dos particulares deve ser precedido de processo, como já afirmamos em outro local: "reza o due process of law que sem prévio processo não é possível a edição de qualquer ato estatal que atinja, ainda que minimamente, o patrimônio dos particulares, entendido aqui em acepção latíssima” (MELLO, Rafael Munhoz de. Processo Administrativo, Devido Processo Legal e a Lei no 9.784/1999, p. 90).

${ }^{13}$ Ver, p. ex., as classificações propostas por FERREIRA, Daniel. Sanções Administrativas, p. 44-48.
} 
A sanção administrativa retributiva esgota-se na aplicação de um mal ao infrator. Trata-se de medida de simples retribuição pela prática da infração, sem qualquer pretensão de ressarcimento do dano causado pela conduta delituosa ou de restauração do status quo ante. A sanção administrativa assim entendida, nas palavras de Rebollo Puig, "no sirve para restablecer la realidad física alterada o los bienes jurídicos lesionados ni para compensar el daño que haya causado". ${ }^{14}$ É dizer, a imposição da sanção retributiva não gera, do ponto de vista jurídico, qualquer benefício à vítima da conduta delituosa, pois "materialmente non restaura l'offesa recata dal delinquente alla vittima e, traverso questa, alla societá", na lição de Zanobini. ${ }^{15}$

Reconhecer que a sanção administrativa retributiva esgota-se na imposição de um mal ao infrator não significa aceitar que a finalidade de tal medida seja a de punir. A finalidade da sanção retributiva, penal ou administrativa, é preventiva: ${ }^{16}$ pune-se para prevenir a ocorrência de novas infrações, desestimulando a prática de comportamentos tipificados como ilícitos. ${ }^{17}$

Já a sanção administrativa ressarcitória não se esgota na imposição de um mal ao infrator, mas vai além: a medida aflitiva imposta pela Administração Pública altera a situação de fato existente, reparando o dano causado à vítima da infração. O ilícito consiste, aqui, na violação do dever geral de não causar danos a terceiros.

Exemplo típico de sanção ressarcitória imposta pela Administração Pública é a cobrança de juros moratórios pelo atraso no recolhimento de tributos, sanção prevista no art. 161 do Código Tributário Nacional. Como ensina Paulo de Barros Carvalho, "sua cobrança não tem fins punitivos", tendo por característica "um traço remuneratório do capital que perma-

\footnotetext{
${ }^{14}$ El Derecho Administrativo Sancionador, p. 267-268.

15 Le Sanzioni Amministrative, p. 6.

16 Daniel Ferreira entende ser "difícil negar que as penas não tenham a finalidade de punir (...) Diferentemente, as sanções administrativas têm por especial objetivo desestimular condutas administrativas reprováveis" (Sanções Administrativas, p. 90). Não parece correto, contudo, diferenciar sob tal aspecto sanção penal e sanção administrativa retributiva. Ambas consistem em medida sancionadora retributiva, cuja finalidade é "desestimular condutas reprováveis". A finalidade da sanção penal não é punir, assim como não é esta a finalidade da sanção administrativa. Pune-se para prevenir, em ambos os casos.

17 "Quando uma sanção é aplicada, o que se pretende com isto é tanto despertar em quem a sofreu um estímulo para que não reincida, quanto cumprir uma função exemplar para a sociedade. Não se trata, portanto, de causar uma aflição, um 'mal', objetivando castigar o sujeito, levá-lo à expiação pela nocividade de sua conduta. O Direito tem como finalidade unicamente a disciplina da vida social, a conveniente organização dela, para o bom convívio de todos e bom sucesso do todo social, nisto se esgotando seu objeto. Donde, não entram em pauta intentos de represália, de castigo, de purgação moral a quem agiu indevidamente" (MELLO, Celso Antônio Bandeira de. Curso de Direito Administrativo, p. 745).
} 
nece em mãos do administrado por tempo excedente ao permitido". ${ }^{18}$ A mesma opinião é compartilhada por Sacha Calmon Navarro Coêlho, que sustenta que a cobrança de juros moratórios pela Administração Pública "visa a indenizar o credor pela indisponibilidade do dinheiro na data fixada em lei para o pagamento da prestação". ${ }^{19}$

Pode-se afirmar que a sanção administrativa retributiva é instituída tendo em vista a pessoa do infrator, infligindo-lhe um mal pela prática do ilícito, com finalidade preventiva. Já a sanção ressarcitória tem como referência a pessoa que sofreu o dano, obrigando o infrator a repará-lo. No primeiro caso a preocupação maior é punir o infrator, aplicando uma medida que sirva de "estímulo para que não reincida" e, ademais, cumpra "uma função exemplar para a sociedade"; ${ }^{20}$ no segundo caso, a preocupação é ressarcir o dano causado ao ofendido.

Tanto a sanção ressarcitória como a retributiva têm a mesma natureza: trata-se de conseqüência negativa que decorre da inobservância de um dever jurídico. ${ }^{21}$ Mas num caso a conseqüência negativa consiste na reparação do dano, restabelecendo-se o status quo ante ou indenizando-se pelo equivalente patrimonial; no outro, a conseqüência negativa é um mal imposto ao infrator, medida que não tem o condão de modificar a situação danosa causada pela conduta ilícita. Daí afirmar Battaglini que "la pena, invece di guarire una ferita, come avviene nel caso di rissarcimento, produce una ferita nuova". ${ }^{22}$

A sanção retributiva é a típica sanção estatal. Há autores que consideram que só é sanção administrativa a medida aflitiva retributiva, sendo a sanção ressarcitória imposta pela Administração Pública estranha ao campo da sanção administrativa. Guido Zanobini defendia tal posição, sustentando que a pena - medida retributiva - seria a sanção típica do direito público (penal ou administrativo), enquanto o ressarcimento do

\footnotetext{
${ }^{18}$ Curso de Direito Tributário, p. 353.

19 Teoria e Prática das Multas Tributárias, p. 77

${ }^{20}$ MELLO, Celso Antônio Bandeira de, op. cit., p. 745.

${ }^{21}$ Nas palavras de Giulio Battaglini, "ambedue le sanzione sono mali sensibili, sofferenze a cui si va incontro per causa dell'atto illecito" (La Pena in Raporto alle Sanzioni Civili ed Amministrative, p. 400-401).

22 Op. e loc. citados. Transcreva-se ainda a seguinte passagem da obra de Giuseppe Bettiol, aplicável não só às sanções penais mas também às sanções administrativas com caráter retributivo: "o direito penal reage sempre com uma sanção à violação do preceito. A sanção, que é a conseqüência jurídica do inadimplemento de um dever, assume no direito penal o nome de pena. Tem ela caráter aflitivo no sentido de que se traduz, do ponto de vista substancial, um mal infligido ao autor de um malefício propter maleficium. Não se trata, na verdade, de reconstituir o status quo ante, a situação de fato que se desenhava antes que o réu, com o seu delito, viesse a alterar; não se trata de proceder ao ressarcimento de um dano e, desta forma, de retornar a uma posição de equilíbrio entre interêsses antagônicos, fim a que tende a sanção civil" (Direito Penal, p. 99).
} 
dano - medida ressarcitória - seria a sanção típica do direito privado. ${ }^{23}$ A mesma posição é defendida, no direito espanhol, por Angel Blasco Pellicer, que entende que o traço característico da sanção administrativa é "el carácter estrictamente punitivo". E completa: "No existe finalidad reparadora como en las sanciones proprias del derecho privado, sino finalidad puramente aflictiva". ${ }^{24}$ No Brasil, o entendimento é adotado por Fábio Medina Osório. ${ }^{25}$

Parece exagerado retirar as medidas sancionadoras com caráter ressarcitório da categoria das sanções administrativas, pois tais medidas são também sanções jurídicas impostas pela Administração Pública, no exercício de função administrativa, em face da ocorrência de um ilícito. Trata-se de uma espécie de sanção administrativa, cujo regime jurídico é distinto do das sanções administrativas que consistem em medidas aflitivas retributivas.

De fato, se a sanção retributiva é um mal imposto a quem age em desconformidade com determinados comandos legais, medida aflitiva que não representa nenhum benefício à vítima, tendo apenas finalidade preventiva, é necessário e natural que alguns princípios sejam observados em sua aplicação: i) a conduta proibida deve ser detalhadamente descrita em lei prévia, para que os particulares saibam exatamente o comportamento indesejado que pode sujeitá-los à imposição da sanção; ii) a sanção somente pode ser imposta a quem agiu de modo voluntário e culposo, pois a finalidade preventiva que justifica a imposição da medida não será atingida se o infrator agiu de modo involuntário ou sem culpa; iii) a sanção deve ser imposta apenas ao sujeito que agiu de modo ilícito, sendo vedada sua transmissão a terceiros que não praticaram o comportamento proibido.

Tais princípios integram o núcleo do regime jurídico punitivo, aplicável a toda manifestação do ius puniendi estatal, seja ele exercido pela aplicação de sanções penais, seja exercido pela imposição de sanções administrativas retributivas.

A situação é distinta nas hipóteses em que a sanção administrativa consiste em medida com caráter ressarcitório. Não se trata, aqui, de infligir um mal ao particular pela prática de uma conduta indesejada, tendo por finalidade prevenir futuras infrações. Trata-se, isso sim, de reparar um dano

\footnotetext{
${ }^{23}$ Le Sanzioni Amministrative, p. 4-5.

${ }^{24}$ Sanciones Administrativas en el Orden Social, p. 14

25 "O que importa ressaltar é que as medidas de cunho ressarcitório não se integram no conceito de sanção administrativa, pois não assumem efeito aflitivo ou disciplinar, mas sim restituitório, reparatório" (Direito Administrativo Sancionador, p. 94-95).
}

A \& C R. de Dir. Administrativo e Constitucional, Belo Horizonte, ano 5, n. 22, p. 25-57, out./dez. 2005 
causado a terceiro. Não se trata de medida que tenha em mira a pessoa do infrator que age de modo ilícito e reprovável, mas sim a pessoa da vítima que sofre danos pela atuação de outrem.

Tendo tais características, à sanção administrativa com caráter ressarcitório não se aplicam os princípios acima referidos, integrantes do regime jurídico punitivo. Não é exigida para a imposição de sanção ressarcitória a descrição detalhada da conduta proibida para que os particulares saibam exatamente o comportamento que é considerado reprovável e que os sujeita à sanção. O comportamento proibido é "causar dano". É admissível a responsabilidade objetiva, indenizando-se a vítima mesmo que o dano tenha sido causado de modo involuntário e sem culpa. E tampouco é vedada a transmissão da sanção ressarcitória, tratando-se de medida que tem por escopo proteger a pessoa que sofreu danos.

O regime jurídico aplicado às sanções administrativas retributivas é assim distinto do que disciplina a imposição de sanções administrativas ressarcitórias. Apenas no primeiro caso tem-se a incidência do regime jurídico punitivo, integrado por princípios usualmente vinculados ao direito penal e desenvolvidos ao longo dos últimos dois séculos. Tal regime não se aplica às sanções administrativas ressarcitórias, cuja função no ordenamento jurídico é outra. O objeto de estudo no presente trabalho são os princípios que se aplicam às sanções administrativas retributivas, impostas no exercício do poder punitivo estatal.

Diga-se por fim que a distinção entre o regime jurídico das sanções retributivas e o das sanções ressarcitórias foi expressamente adotada pela Constituição Federal de 1988, que no inciso XLV do art. $5^{\circ}$ veda a transmissão da sanção retributiva ("nenhuma pena passará da pessoa do condenado") mas não a transmissão da sanção ressarcitória ("podendo a obrigação de reparar o dano e a decretação de perdimento de bens ser, nos termos da lei, estendida aos sucessores e contra eles executadas"). ${ }^{26}$ É dizer, a distinção aqui propugnada encontra guarida no próprio texto constitucional.

\section{O princípio da proporcionalidade e o direito administrativo sancionador}

\footnotetext{
${ }^{26}$ Na vigência da Constituição Federal de 1967, que continha dispositivo semelhante, ensinava Régis Fernandes de Oliveira o seguinte: "Parece-nos deva ter aplicação o princípio da pessoalidade das sanções, como prevê o $\S 13^{\circ}$ do art. 153 da CF. (...) Transmitem-se apenas as sanções reparatórias. Já as punitivas, como objetivam apenas castigar o infrator, para que não torne a descumprir o comando normativo, aplicam-se apenas ao próprio infrator, em obediência ao princípio mencionado" (Infrações e Sanções Administrativas, p. 15).
} 


\subsection{Estado de Direito e proporcionalidade}

O princípio da proibição do excesso ou da proporcionalidade é um dos corolários do Estado de Direito. ${ }^{27}$ Trata-se, como ensina Frank Moderne, de um "principe propre à l'État de droit contemporain", ${ }^{28}$ que impõe ao ente estatal moderação no seu agir, mormente em situações em que a esfera jurídica dos particulares seja atingida. ${ }^{29}$

Num Estado de Direito a atuação dos agentes estatais deve ser moderada, jamais excessiva. Ser moderada significa estar adstrita a limites estabelecidos no ordenamento jurídico. ${ }^{30}$ Se é excessiva ou desproporcional, a atuação do Estado ultrapassa os limites que lhe foram impostos, sendo portanto ilegítima e arbitrária. O princípio da proporcionalidade tem no sistema jurídico, assim, o papel de "cláusula geral anti-arbítrio", na feliz expressão de Helenilson Cunha Pontes. ${ }^{31}$

Vale lembrar que o Estado de Direito surge justamente como resposta à arbitrariedade vigente no Estado de Polícia, no qual a atuação dos entes estatais não enfrentava limites jurídicos. O Estado de Direito submetese ao ordenamento jurídico, encontrando nas normas jurídicas limites à sua ação. Num Estado de Direito os entes estatais agem no exercício de competências previstas no ordenamento, que lhes são outorgadas para o atendimento do interesse público. O princípio da proporcionalidade exige que tais competências sejam exercidas na medida estritamente necessária ao atendimento do interesse público a elas relacionado. ${ }^{32}$

O princípio da proibição do excesso ou da proporcionalidade tem como corolários os sub-princípios i) da adequação, ii) da necessidade e

\footnotetext{
${ }^{27}$ CANOTILHO, José Joaquim Gomes. Direito Constitucional, p. 261; HESSE, Konrad. Elementos de Direito Constitucional da República Federal da Alemanha, p. 158-159; FROMONT, Michel. République Fédéral d'Allemagne: L'État de Droit, p. 1.212-1.214.

28 Sanctions Administrative et Justice Constitutionnelle, p. 263.

29 "L'autre grand principe non écrit est celui de la proportionnalité qui prohibe toute atteinte excessive aux droits ou à la situation d'un individu et qui impose donc à l'État une obligation de modération" (FROMONT, Michel, op. cit., p. 1.213).

30 Por essa razão, Paulo Bonavides considera que o princípio da proporcionalidade, "cânone do Estado de direito", "tolhe toda a ação ilimitada do poder do Estado" (Curso de Direito Constitucional, p. 397).

${ }_{31}$ O Princípio da Proporcionalidade e o Direito Tributário, p. 57.

${ }^{32}$ Ao analisar o princípio da proporcionalidade, ensina Celso Antônio Bandeira de Mello que "as competências administrativas só podem ser validamente exercidas na extensão e intensidade proporcionais ao que seja realmente demandado para cumprimento da finalidade de interesse público a que estão atreladas. Segue-se que os atos cujos conteúdos ultrapassem o necessário para alcançar o objetivo que justifica o uso da competência ficam maculados de ilegitimidade, porquanto desbordam do âmbito de competência" (Curso de Direito Administrativo, p. 101).
} 
iii) da proporcionalidade em sentido estrito. ${ }^{33} 34$

O princípio da adequação exige que os atos estatais tenham aptidão para atingir o resultado que se pretende. Ao exercer uma competência, o ente estatal tem em mira uma específica finalidade, devendo a medida adotada ser adequada ao seu alcance. Nas palavras de Michel Fromont, o Estado "doit s'assurer que la mesure prise est susceptible d'atteindre l'objectif choisi". ${ }^{35}$ É dizer, o meio utilizado pelo agente estatal deve ser idôneo para atingir o fim que se deseja. ${ }^{36}$ Sendo necessariamente um interesse público o fim do agir estatal, o ato deve ser adequado para a sua satisfação.

Por força do princípio da necessidade, o Estado deve adotar, ao buscar seus objetivos, a medida menos gravosa aos particulares. Se há dois meios adequados para atingir um mesmo fim, deve ser adotado pelo Estado o que represente menor sacrifício dos interesses privados. ${ }^{37}$ Trata-se de um limite quantitativo imposto ao Estado, que impõe a escolha da medida que assegure a satisfação do interesse público com o menor prejuízo aos demais interesses envolvidos.

O princípio da proporcionalidade em sentido estrito veda a utilização excessiva ou desproporcional da competência outorgada ao agente estatal. Uma vez definida a medida adequada e necessária ao atendimento do fim desejado, deve ainda o Estado praticá-la na exata proporção exigida pela situação. Em outras palavras, o meio empregado deve ser proporcio-

\footnotetext{
${ }^{33}$ A origem de tal entendimento está no direito alemão, como explica Aldo Sandulli: "il principio di proporzionalità ha vissuto, a partir dagli anni cinquanta, una vera e propria espansione. (...) Questa espansione ha condotto ad una sensibile evoluzione del principio, non priva de conseguenze, come vedremo, per quegli ordinamenti dell'Europa continentale che ne hanno subito l'influenza. La caratteristica fondamentale della proporzionalità nel sistema tedesco, difatti, è rinvenibile nella duplicità del principio, il quale può essere inteso sia 'in senso lato', sia, nell'ambito di esso, 'in senso stretto'". No sentido lato, continua Sandulli, o princípio da proporcionalidade possui "tre distinti elementi, ciascuno dei quali dotato di peculiari ed autonome caractteristiche. (...) Il primo è quello di idoneità, (...), il secondo è quello di necessarietà, (...), il terzo è quello di Abwägung o di Proportionalität (proporzionalità in senso stretto)" (La Proporzionalità dell'azione Amministrativa, p. 63-66). No mesmo sentido, veja-se a lição de Helenilson Cunha Pontes: "A jurisprudência do Tribunal Constitucional Federal [alemão], não obstante tenha albergado no passado uma certa variação terminológica, definiu, a partir dos anos sessenta, uma concepção metodologicamente estável do conteúdo normativo do princípio da proporcionalidade, e dos três aspectos que o compõem: adequação, necessidade e proporcionalidade em sentido estrito" (op. cit., p. 62).

${ }^{34}$ CANOTILHO, Gomes, op. cit., p. 264-265; FROMONT, Michel, op. cit., p. 1.214; BONAVIDES, Paulo, op. cit., p. 360-366; GUERRA FILHO, Willis Santiago. Processo Constitucional e Direitos Fundamentais, p. 66-68.

${ }^{35}$ Op. cit., p. 1.214

36 "La valutazione di idoneità attiene, pertanto, alla coerenza del mezzo impiegato, cioè se, data la situazione di fatto, il mezzo utilizzato dall'amministrazione sia idoneo a produrre apprezzabili risultati. Si opera, dunque, un accertamento dell'idoneità del mezzo impiegato dall'autorità amministrativa" (SANDULLI, Aldo, op. cit., p. 368).

37 "O princípio da exigibilidade, também conhecido como 'princípio da necessidade' ou da 'menor ingerência possível', coloca a tónica na ideia de que o cidadão tem direito à menor desvantagem possível. Assim, exigirse-ia sempre a prova de que, para a obtenção de determinados fins, não era possível adoptar outro meio menos oneroso para o cidadão" (CANOTILHO, Gomes, op. cit., p. 264).
} 
nal ao fim desejado. ${ }^{38}$ Há aqui também um limite quantitativo ao exercício do poder estatal: a competência deve ser exercida na "justa medida" para atingir o objetivo a ela relacionado. ${ }^{39}$

Enfim, o princípio da proibição do excesso ou proporcionalidade exige que o ato estatal seja adequado ao alcance do fim pretendido e cause o menor gravame possível aos particulares. Reza ainda o princípio que o ato adequado e necessário seja praticado na medida exata para o alcance do seu fim.

\subsection{Proporcionalidade em sentido estrito e sanção administrativa}

O princípio da proporcionalidade ocupa papel relevante no direito administrativo sancionador, cujas normas disciplinam atuação estatal das mais agressivas aos particulares. As sanções administrativas são um mal imposto pela Administração Pública aos indivíduos que praticam infração administrativa. Trata-se de medida que atinge de modo negativo a esfera jurídica dos particulares, razão pela qual deve ser aplicada com observância do princípio da proibição do excesso e seus corolários: adequação, necessidade e proporcionalidade em sentido estrito. ${ }^{40}$ Para que seja válida, a sanção administrativa deve ser adequada, necessária e proporcional.

O princípio da proporcionalidade tem destaque no campo punitivo desde os primórdios da evolução do Estado de Direito. De fato, já em 1789 a Declaração dos Direitos do Homem e do Cidadão estabelecia que "la loi ne doit établir que des peines strictement et évidemment nécessaire" (art. $8^{\circ}$ ), dispositivo que pode ser considerado como a origem do princípio da proporcionalidade no domínio do poder punitivo estatal. ${ }^{41}$

Em seu sentido estrito, o princípio da proporcionalidade veda a imposição de sanções administrativas excessivas e desproporcionais à situação fática que serve de motivo para a imposição da punição. A intensidade da sanção administrativa deve corresponder à gravidade da conduta ilícita praticada pelo infrator: quanto mais grave a conduta, mais intensa deve ser a sanção. "Adapter la sanction à la gravité de l'infraction, éviter les punitions

38 " $\|$ doit censurer une mesure qui, tout en étant adéquate et nécessaire, est d'une sévérité exagérée eu égard au but poursuivi, c'est-à-dire lorsqui'il y a disproportion entre le moyen et le but" (FROMONT, Michel, op. cit., p. 1.214).

${ }^{39}$ CANOTILHO, Gomes, op. cit., p. 265.

40 "El principio de proporcionalidad (con sus tres escalones: idoneidad, necesidad y proporcionalidad en sentido estricto) es un principio de tradicional aplicación a todas las medidas públicas restrictivas de derechos o libertades de los ciudadanos y particulamente a las de contenido sancionador, tanto en el plano normativo como en el aplicativo, exigiendo una correlación entre la gravedad de la infracción y la sanción" (VALENCIA MATTÍN, Germán. Derecho Administrativo Sancionador y Principio de Legalidad, p. 158).

${ }^{41}$ Les Pouvoirs de l'Administration dans le Domaine des Sanctions, p. 58; MODERNE, Franck. Sanctions Administratives et justice Constitutionnelle, p. 263. 
excessives au regard des faits qui la motivent": ${ }^{42}$ eis aí a faceta mais visível do princípio da proporcionalidade no direito administrativo sancionador.

Para definir a "justa medida" da sanção administrativa é preciso sopesar as circunstâncias fáticas de cada infração. É arbitrária a sanção aplicada sem consideração às peculiaridades do caso concreto, essenciais à definição da intensidade da medida sancionadora a ser aplicada e, de conseqüência, à observância do princípio da proporcionalidade. ${ }^{43}$

A importância da avaliação das particularidades da situação fática aumenta na mesma proporção que a discricionariedade do agente administrativo na definição da sanção. Não é raro que a lei arrole diversas espécies de sanção e atribua à Administração Pública a definição da medida a ser aplicada no caso concreto. Ou ainda, pode o legislador estabelecer limites mínimo e máximo à sanção administrativa, cabendo ao agente administrativo definir a sanção dentro do espaço delimitado pela lei. Em casos tais, o exercício da competência discricionária deve atentar para a gravidade da conduta praticada e suas particularidades.

Ocorre que o legislador não define de modo absoluto e vinculado a intensidade da sanção justamente por considerar que as peculiaridades de cada caso concreto têm relevância na definição da punição administrativa justa. ${ }^{44} 45$ Tais peculiaridades podem ser analisadas somente pelo agente competente para impor a sanção, devendo necessariamente ser utilizadas como parâmetro para a definição da intensidade da medida sancionadora, sob pena de violação ao princípio da proporcionalidade.

Serve também o princípio da proporcionalidade em sentido estrito para evitar que o legislador crie sanções administrativas excessivamente

42 MODERNE, Franck, op. cit., p. 263.

43 "A aplicação genérica e indiscriminada da sanção máxima aos servidores envolvidos em processo administrativo, sem que observada a diversidade das condutas praticadas, fere os princípios da individualização e da proporcionalidade da reprimenda" (STJ, MS n 7.077/DF, DJU, 11.6.2001, p. 90).

44 "A regra de direito, como é óbvio, pretende sempre e sempre a medida capaz de atender excelentemente ao interesse público. Ora, dadas a multiplicidade e variedade de situações fáticas passíveis de ocorrerem as quais serão distintas entre si pelas circunstâncias que as envolvem e pela coloração que tenham -, é preciso que o agente possa, em consideração à fisionomia própria de cada qual, proceder à eleição da medida idônea para atingir de modo perfeito o objetivo da regra aplicanda. Se a lei todas as vezes regulasse vinculadamente a conduta do administrador, padronizaria sempre a solução, tornando-a invariável mesmo perante situações que precisariam ser distinguidas e que não se poderia antecipadamente catalogar com segurança, justamente porque a realidade do mundo empírico é polifacética e comporta inumeráveis variantes. Donde, em muitos casos, uma predefinição normativa estanque levaria a que a providência por ela imposta conduzisse a resultados indesejáveis" (MELLO, Celso Antônio Bandeira de. Curso de Direito Administrativo, p. 845).

45 "Frente a la tesis de la pretendida pluralidad de soluciones justas que se cree hallar en la escala establecida por la ley, lo que determina una potestad discrecional de la Administración, creo que es preciso recurrir a una interpretación diversa y preguntarse, en primer lugar, cuál será la ratio legis de una norma que, por ejemplo, a la falta muy grave le señala cuatro posibles sanciones de muy diversa gravedad. A este respecto, no parece que la norma pretenda dar un derecho de libre opción a la Administración, sino que más bien es la 
graves. Tendo força constitucional, o princípio da proporcionalidade impõe limites à criação legislativa de sanções administrativas. O Supremo Tribunal Federal, p. ex., considerou inconstitucional sanção tributária com caráter confiscatório, em face da "desproporção entre o desrespeito à norma tributária e sua conseqüência jurídica, a multa” ${ }^{46}$

\subsection{Vedação às sanções permanentes}

Cabe aqui mencionar que é vedada a criação de sanção administrativa permanente, que por sua exagerada gravidade vai de encontro ao princípio da proporcionalidade em sentido estrito. Sanção administrativa permanente representa punição excessiva, restringindo o exercício de certo direito por toda a vida do indivíduo.

É a própria Constituição Federal de 1988 que considera excessiva a sanção permanente, ao proibir a imposição de medidas sancionadoras com caráter perpétuo (art. $5^{\circ}$, inciso XLVII, b). Sendo assim, pode-se afirmar, como Geraldo Ataliba, que "repugna ao espírito do nosso sistema jurídico e agride a letra das normas maiores nele inscritas, a perpetuidade das punições". ${ }^{47} \mathrm{O}$ entendimento é adotado tanto pelo Supremo Tribunal Federal como pelo Superior Tribunal de Justiça, que já reconheceram, p. ex., a inconstitucionalidade da sanção administrativa prevista no inciso IV do art. 44 da Lei $\mathrm{n}^{\circ}$ 4.595/1964 (inabilitação permanente para o exercício de cargos de direção ou gerência em instituição financeira). ${ }^{48}$

\section{0 princípio da culpabilidade}

\subsection{Proporcionalidade e culpabilidade: exigência de dolo ou culpa}

O princípio da proporcionalidade tem ainda outra importante conseqüência no campo do direito administrativo sancionador: exige que a sanção administrativa retributiva seja aplicada apenas à ação que, imposibilidad material de tipificar todas las infracciones, con sus circunstancias objetivas y subjetivas, lo que obliga a establecer estos criterios generales que, frente al caso concreto, exigirán, en primer lugar, buscar los principios generales para interpretar la norma y completarla, y de esta forma aplicar luego la única solución adecuada y que se ajusta a la voluntad del ordenamiento. Es decir, al establecerse diversos tipos de sanciones para una infracción, no se pretende por la norma remitiese al criterio opcional del órgano sancionador, sino a los principios generales" (TORNOS MAS, Joaquín. Infracción y Sanción Administrativa: el Tema de su Proporcionalidad en la Jurisprudencia Contencioso-administrativa, p. 6). O princípio que cumpre tal papel, segundo Tornos Mas, é o da proporcionalidade (id., p. 7).

${ }^{46}$ ADIn n' 551-1/RJ, DJU 14.2.2003. No caso analisado pelo STF, os dispositivos considerados inconstitucionais integravam o Ato das Disposições Constitucionais Transitórias da Constituição do Estado do Rio de Janeiro e estabeleciam que "as multas conseqüentes do não recolhimento dos impostos e taxas estaduais aos cofres do Estado não poderão ser inferiores a duas vezes o seu valor", bem como que "as multas conseqüentes da sonegação dos impostos ou taxas estaduais não poderão ser inferiores a cinco vezes o seu valor".

47 Inconstitucionalidade de Sanções Permanentes, p. 23. No mesmo sentido, FERREIRA, Daniel. Sanções Administrativas, p. 135; EIZIRIK, Nelson. Reforma das S/A e do Mercado de Capitais, p. 252.

48 "Apesar de não existir previsão legal possibilitando a revisão ou reabilitação da pena de inabilitação permanente para o exercício de cargos de direção na administração ou gerência em instituições financeiras, prevista no art. 44, § 4 , IV da Lei 4.595/64, é inadmissível que se fale na inocorrência de tais procedimentos,

A \& C R. de Dir. Administrativo e Constitucional, Belo Horizonte, ano 5, n. 22, p. 25-57, out./dez. 2005 
além de típica e ilícita, seja também culpável. A imposição de sanção administrativa retributiva depende da culpa do infrator, em função do subprincípio da adequação, corolário do princípio da proibição do excesso ou da proporcionalidade, que por sua vez decorre do princípio fundamental do Estado de Direito, previsto no art. $1^{\circ}$ da Constituição Federal de 1988.

Com efeito, não é adequada a medida sancionadora aplicada a sujeito que não agiu de modo doloso ou ao menos com culpa stricto sensu (negligência, imperícia ou imprudência). Para além de tais hipóteses, o sujeito que praticou a conduta típica agiu licitamente e com a diligência exigida pelas circunstâncias. Ou seja, não obstante a diligência, perícia e prudência no agir, voltado a resultado lícito, ocorreu comportamento típico.

Ora, a finalidade da sanção administrativa é a prevenção da ocorrência de novas infrações administrativas. Como já ressaltado, a punição em que consiste a sanção administrativa tem finalidade preventiva: aplicase uma medida negativa ao infrator para prevenir a ocorrência de futuras infrações. A finalidade preventiva tem em mira a pessoa do infrator (prevenção especial) e os demais membros da sociedade (prevenção geral): o infrator não mais praticará o ilícito por receio de receber nova sanção, além de servir como exemplo para os demais potenciais infratores. ${ }^{49}$ Ou ainda, como ensina Ángeles de Palma Del Teso, "la necesidad de la sanción administrativa deriva de fines preventivos, al objeto de evitar que el autor cometa en el futuro nuevas infracciones y confirmar a los ojos de la generalidad la vigencia de la norma jurídica". ${ }^{50}$

Pois bem. A sanção administrativa retributiva só cumpre sua finalidade preventiva se aplicada a quem age de modo doloso ou culposo. É dizer, se aplicada a quem pratica de modo consciente e voluntário a conduta típica (dolo), ou a quem pratica voluntariamente um comportamento lícito mas age com negligência, imperícia ou imprudência, causando resultado

pois, conforme interpretação do art. $5^{\circ}, \mathrm{XLVI}$ e XLVII, b e seu $\S 2^{\circ}$, da $\mathrm{CF}$, é vedada a aplicação de qualquer pena de caráter perpétuo" (STF, RE 154.134-2/SP, RT 773/155). E ainda: "I - Os direitos e garantias expressamente previstos na Constituição Federal não excluem outros tantos decorrentes do regime e dos princípios nela adotados (art. $5^{\circ}, \mathrm{LXXVII}, \S 2^{\circ}$ ). II - A vedação às penas de caráter perpétuo não pode ser interpretada restritivamente, estendendo-se às penalidades de suspensão e interdição de direitos capitulados no inciso LXVI, letra e, do mesmo artigo. III - Segurança concedida" (STJ, MS n 1.119/DF, RSTJ 28/279).

49 "Caracteriza-se a chamada prevenção geral da pena pelo efeito de intimidação que a ameaça de sua imposição ou a sua aplicação ou execução concretas possam produzir no seio da comunidade. (...) Por prevenção especial entende-se o objetivo de evitar que o sujeito cometa novas infrações. Trata-se de proporcionar ao condenado, através da execução da pena, caminhos opostos à resistência" (DOTTI, René Ariel. Curso de Direito Penal - Parte Geral, p. 434)

${ }^{50}$ El Principio de Culpabilidad en el Derecho Administrativo Sancionador, p. 44. Transcreva-se ainda a lição de Celso Antônio Bandeira de Mello: "A razão pela qual a lei qualifica certos comportamentos como infrações administrativas, e prevê sanções para quem nelas incorra, é a de desestimular a prática daquelas 
tipificado como infração administrativa (culpa stricto sensu). ${ }^{51}$

Ocorre que a finalidade preventiva só é atingida se do sujeito que sofre os efeitos da sanção fosse possível exigir conduta distinta da que foi praticada, evitando assim o resultado típico alcançado. ${ }^{52}$ Agindo com dolo, o indivíduo decide conscientemente praticar a conduta típica. Se escolhe agir dessa forma, pode também escolher agir de outra, servindo a sanção como estímulo à escolha que trilhe os caminhos da legalidade. No caso da conduta meramente culposa, em que o sujeito age com negligência, imperícia ou imprudência, também pode ser adotado modo de agir diverso, diligente e prudente, evitando-se assim a configuração do comportamento proibido. A sanção administrativa aplicada ao sujeito que age com dolo ou culpa serve como estímulo à mudança: se praticou deliberadamente a conduta típica, a sanção o estimula a não reincidir; se a praticou por negligência, imperícia ou imprudência, a sanção o incentiva a ser mais diligente e cuidadoso no seu agir. Previne-se, de tal maneira, a prática de novas infrações administrativas.

A situação é diferente se não há dolo ou culpa na ação do indivíduo. Ele não pratica a conduta típica de modo voluntário e consciente (dolo). Tampouco deixa de observar o dever de diligência que a todos é atribuído numa sociedade (culpa stricto sensu). Seu agir voluntário e consciente é voltado à prática de conduta lícita, e ele age com diligência em tal intento. Sendo assim, o comportamento exigido pelo ordenamento jurídico é atendido: o particular não pratica de modo voluntário e consciente a conduta típica e não age com negligência, imperícia ou imprudência.

\footnotetext{
condutas censuradas ou constranger ao cumprimento das obrigações. Assim, o objetivo da composição das figuras infracionais e da correlata penalização é intimidar eventuais infratores, para que não pratiquem os comportamentos proibidos ou para induzir os administrados a atuarem na conformidade de regra que lhes demanda comportamento positivo. Logo, quando uma sanção é aplicada, o que se pretende com isto é tanto despertar em quem a sofreu um estímulo para que não reincida, quanto cumprir uma função exemplar para a sociedade" (op. cit., p. 744-745).

51 Para Heleno Cláudio Fragoso, "o dolo é vontade de realização da conduta típica" (Lições de Direito Penal - A Nova Parte Geral, p. 172). E completa: "no caso da culpa, no entanto, a vontade é dirigida a outros fins. Não obstante, o agente causa o resultado por que atuou sem observar as normas de atenção, cuidado ou diligência impostas pela vida de relação, tendo-se em vista as circunstâncias do fato concreto" (id., p. 220). Assim, a conduta meramente culposa "é a que se realiza com negligência, imprudência ou imperícia, ou seja, violando um dever objetivo de cuidado, atenção ou diligência" (ibid., p. 219).

52 "A pena criminal assim entendida como instrumento de intimidação, isto é, como medida de prevenção geral, só adquire algum sentido se a correlacionarmos com a noção de evitabilidade do fato praticado. Vale dizer: só se pode intimidar o homem, com algum proveito, com a ameaça da pena, de dor ou de sofrimento, para que deixe de praticar fatos indesejáveis, nocivos ao semelhante, à tribo, à comunidade, à sociedade, quando tais fatos indesejáveis são evitáveis, ou, por outras palavras, quando esteja na esfera do indivíduo membro fazer ou não fazer o que se quer evitar por meio da ameaça referida" (TOLEDO, Francisco de Assis. Princípios Básicos de Direito Penal, p. 28).
} 
Mas não obstante a correção do seu agir, o resultado de sua ação é evento tipificado como infração administrativa. Pergunta-se: que função preventiva exerce a sanção administrativa em casos tais? Estimular o sujeito a não mais agir de modo diligente?

Se não há dolo ou culpa, a aplicação da sanção administrativa retributiva não previne a ocorrência futura de comportamentos tipificados como infrações administrativas. $\mathrm{O}$ indivíduo que sem culpa praticou o comportamento típico não mudará seu modo de agir em face da imposição da sanção. E nem é possível exigir a mudança, pois nada de ilegal havia em sua conduta: ele não desejou a conduta típica e tampouco agiu com negligência, imperícia ou imprudência. De conseqüência, não há razão que justifique a imposição de uma medida sancionadora cujo propósito é estimular a mudança de comportamento do infrator (prevenção especial).

Utilize-se exemplo singelo para ilustrar o que foi afirmado. Dispõe o Código de Trânsito Brasileiro que é infração administrativa entregar a direção de veículo a pessoa que não possua Carteira Nacional de Habilitação - CNH (Lei no 9.503/1997, arts. 162, inciso I e 163). Se o infrator sabe que a pessoa a quem entrega a direção não é portadora de CNH e ainda assim pratica a conduta de modo voluntário, age com dolo. Se o infrator entrega a direção a outra pessoa e não se preocupa em verificar se ela possui $\mathrm{CNH}$, age com culpa stricto sensu. Em tal caso, a vontade não é dirigida à prática da conduta típica (entregar a direção de veículo a pessoa que não possua $\mathrm{CNH}$ ), mas sim a outro fim, lícito: entregar a direção de veículo a outrem. Por negligência e imprudência, contudo, o resultado acaba sendo o evento descrito no citado diploma legal.

Em ambos os casos a sanção administrativa vai cumprir sua finalidade preventiva, sendo medida apta e adequada a estimular a mudança de comportamento do infrator: não mais entregar direção a quem não é portador de $\mathrm{CNH}$; verificar, antes de entregar a direção de veículo a outrem, se a pessoa possui $\mathrm{CNH}$.

Imagine-se porém a seguinte situação: Fulano entrega a Beltrano a direção de veículo, tendo antes tomado o cuidado de verificar que este último era portador de CNH. Sob a fiscalização de agentes administrativos, descobre-se que Beltrano na realidade não possuía $\mathrm{CNH}$, e que apresentara a Fulano uma via falsificada. Note-se que a conduta típica foi praticada: Fulano voluntariamente entregou a direção de veículo a pessoa que não possuía CNH. Não agiu com dolo, pois não desejava praticar a conduta 
típica. Tampouco agiu com culpa, pois observou o dever de diligência ao verificar se Beltrano era portador de CNH.

Seria adequada a imposição de sanção administrativa em caso semelhante? A finalidade preventiva da sanção administrativa seria atingida? Faria sentido aplicar a Fulano uma medida que tivesse por fim estimulá-lo a não mais agir da mesma forma? Parece claro que a resposta a tais questões é negativa.

E nem se argumente que a imposição da sanção administrativa, mesmo sem que tenha havido atuação culposa, pode servir ao propósito de prevenção geral. De início, note-se que o entendimento vai de encontro ao princípio constitucional da dignidade da pessoa humana (CF, art. $1^{\circ}$, inciso III), eis que um indivíduo seria injustamente submetido à sanção administrativa, já que não agiu de modo ilícito, com o único propósito de servir de exemplo aos demais integrantes da coletividade ${ }^{53} \mathrm{Em}$ tal situação ocorreria a "instrumentalización de la persona al imponer una pena", como afirma Günther Jakobs, situação obviamente contrária ao princípio da dignidade da pessoa humana. ${ }^{54}$

Ademais, a imposição de sanção administrativa retributiva a indivíduo que não agiu com dolo ou culpa nem mesmo serve ao propósito de prevenção geral. O objeto da prevenção é a conduta típica praticada com voluntariedade e consciência (dolo) ou a negligência, imprudência ou imperícia que conduzem a resultado ilícito, ainda que não desejado pelo infrator (culpa stricto sensu). Não há razão para prevenir a ocorrência de conduta que não foi dolosa e nem mesmo culposa.

Se não alcança sua finalidade preventiva, especial e geral, a sanção administrativa retributiva é medida inadequada nos casos em que não há dolo ou culpa stricto sensu. É inadequada em face da inaptidão para atingir seu fim, que é prevenir a ocorrência da conduta típica. Trata-se de medida inútil, portanto, como bem nota Ángeles de Palma Del Teso: "la pena proporcional a la culpabilidad es la única pena útil". ${ }^{55} \mathrm{E}$ complementa: "sólo la sanción sentida como adecuada, tanto por el que la soporta como por la sociedad, cumple su finalidad de prevención especial y general". ${ }^{56}$

\footnotetext{
53 "En un Estado Democrático es fundamental el derecho a la dignidad de la persona, que se lesionaría al sancionar a un ciudadano que no ha trangredido voluntariamente la norma o ha actuado con la diligencia debida. El Derecho punitivo no puede entrar en juego cuando las personas se conducen con respeto al Ordenamiento, pues ello sería contrario a la seguridad jurídica que nuestra Constitución garantiza. Si se castiga a alguien por un hecho no querido ni imprudente o por un hecho ajeno se vulneran princípios básicos en un Estado Democrático" (TESO, Ángeles de Palma Del, op. cit., p. 54).

${ }^{54}$ Culpabilidad en Derecho Penal, p. 11-12.
}

A \& C R. de Dir. Administrativo e Constitucional, Belo Horizonte, ano 5, n. 22, p. 25-57, out./dez. 2005 
Sendo medida inapta a atingir sua finalidade, a sanção administrativa retributiva imposta a quem age sem dolo ou culpa fere o princípio da adequação, corolário do princípio da proporcionalidade que exige que o meio utilizado pelo agente estatal seja idôneo para atingir o fim previsto na lei. De conseqüência, o princípio da proporcionalidade tem como corolário, no direito administrativo sancionador, o princípio da culpabilidade. ${ }^{57}$

Tratando-se de princípio constitucional, como defendido no presente trabalho, o legislador infraconstitucional não pode afastar a culpabilidade do campo do direito administrativo sancionador, outorgando à Administração Pública competência para impor sanções administrativas retributivas independentemente da culpa do particular. Adota-se aqui tese encampada por parte da doutrina pátria, como se vê nas obras de Fábio Medina Osório, ${ }^{58}$ Heraldo Garcia Vitta ${ }^{59}$ e Edilson Pereira Nobre Júnior. ${ }^{60}{ }^{61} \mathrm{O}$ mesmo entendimento é compartilhado por diversos doutrinadores que analisaram o tema à luz da dúbia redação do art. 136 do Código Tributário Nacional. ${ }^{62} 63$

\subsection{Insuficiência da mera voluntariedade}

Há todavia autorizadas vozes que sustentam entendimento diverso,

\footnotetext{
${ }^{55}$ Op. cit., p. 45.

${ }^{56}$ Id., p. 148

57 Da mesma forma, ensina Fábio Medina Osório: "Culpabilidade é uma exigência inarredável, para as pessoas físicas, decorrente da fórmula substancial do devido processo legal e da necessária proporcionalidade das infrações e das sanções, sendo imprescindível uma análise da subjetividade do autor do fato ilícito, quando se trate de pessoa humana" (Op. cit., p. 315). Em sentido semelhante, reconhecendo a origem da culpabilidade no princípio da proporcionalidade, afirma Angel Blasco Pellicer que "el principio de culpabilidad puede inferirse de los principios de legalidad y prohibición del excesso (artículo 25.1 CE) o de las exigencias inherentes al Estado de Derecho" (Sanciones Administrativas en el Orden Social, p. 34).

58 "Ficaria o princípio da culpabilidade adstrito, na produção de seus efeitos e reflexos, ao campo penal? Parece-me evidente que não. E isso porque tal princípio não tem natureza essencialmente penal, mas sim constitucional. É um princípio constitucional genérico, que limita o poder punitivo do Estado. Trata-se, nesse passo, de garantia individual contra o arbítrio, garantia que se corporifica em direitos fundamentais da pessoa humana" (Direito Administrativo Sancionador, p. 314-315).

59 "No regime jurídico-constitucional desse porte, no qual se acentuam a República, a Democracia e o Estado de Direito, não podemos conceber haja infrações administrativas, diante de mera voluntariedade, sem qualquer análise da culpa ou do dolo do infrator" (A Sanção no Direito Administrativo, p. 43).

60 "Somos pela impossibilidade de responsabilidade objetiva nas infrações administrativas. Há necessidade de se demonstrar que a ação antijurídica adveio de culpabilidade. O que se faculta ao legislador e, mesmo assim, desde que seja expresso, é dispensar o dolo, contentando-se com a culpa em sentido estrito" (Sanções Administrativas e Princípios de Direito Penal, p. 141).

${ }^{61}$ Mencione-se ainda a opinião de Modesto Carvalhosa (A Nova Lei das S/A, p. 500), Nelson Eizirik (Reforma das S/A e Mercados de Capitais, p. 194-195) e José Alexandre Tavares Guerreiro (Sobre o Poder Disciplinar da CVM, p. 75-76), autores que defendem a vigência do princípio da culpabilidade no âmbito da atuação punitiva exercida pela Comissão de Valores Mobiliários.
} 
reconhecendo que a imposição de sanção administrativa não depende de dolo ou culpa do infrator, bastando a voluntariedade da conduta. É a posição defendida por Régis Fernandes de Oliveira, ${ }^{64}$ Daniel Ferreira ${ }^{65}$ e Celso Antônio Bandeira de Mello. ${ }^{66}$

A voluntariedade diz respeito à ação praticada pelo particular. Para que se configure infração administrativa é necessário que o agente tenha praticado uma conduta de modo voluntário, movido por "impulso anímico", nas palavras de Régis Fernandes de Oliveira ${ }^{67}$ Ao exigir voluntariedade, os referidos autores afastam a possibilidade de sanção administrativa ser imposta a quem age de modo autômato, sem desejar, sem que seja o agir conseqüência de um comando de vontade, tal qual ocorre com atos reflexos, em situações de coação absoluta irresistível ou de caso fortuito. ${ }^{68}$ O entendimento é correto, pois sem voluntariedade não há ação imputável ao intelecto do homem, mas sim mero movimento material decorrente

\footnotetext{
${ }^{62}$ Veja-se a lição de Alberto Xavier: "A primeira conclusão é, portanto, de que o art. 136, ao invés do que certas posições preconizaram, não consagra a responsabilidade objetiva, mas se trata ainda de expressão da responsabilidade subjetiva, embora o legislador tenha declarado a irrelevância do dolo. A minha segunda observação vai no sentido de que me parece que, em qualquer caso, a responsabilidade penal objetiva seria inconstitucional, e isto por invocação do $\S 13^{\circ}$ do art. 153, que estabelece o princípio da pessoalidade da pena e da individualização da pena" (VI Curso de Especialização em Direito Tributário, p. 729). Na mesma ocasião, o entendimento foi também compartilhado por Geraldo Ataliba e Hector Villegas, como se vê na mesma obra (p. 731-733). Ver ainda Ruy Barbosa Nogueira, Curso de Direito Tributário, p. 199; Eduardo Fortunato Bim, A Inconstitucionalidade da Responsabilidade Objetiva no Direito Tributário Sancionador, p. 153 et seq.; Carlos César Sousa Cintra, Reflexões em torno das Sanções Administrativas Tributárias, p. 85. Em sentido contrário, admitindo que a lei possa estabelecer sanção tributária sem observância do princípio da culpabilidade, ver Paulo de Barros Carvalho, Curso de Direito Tributário, p. 348; Sacha Calmon Navarra Coêlho, Manual de Direito Tributário, p. 407-408; Ives Gandra da Silva Martins, Da Sanção Tributária, p. 70; Ricardo Lobo Torres, Curso de Direito Financeiro e Tributário, p. 238-239.

${ }^{63}$ A jurisprudência do STJ firmou o entendimento de que é subjetiva a responsabilidade nas infrações tributárias, como se vê da ementa do seguinte julgado: "O art. 136 do Código Tributário Nacional, no que toca à infração da lei tributária, deve ser examinado em harmonia com o art. 137, também do CTN, que consagra a responsabilidade subjetiva" (REsp. n 68.089/SP, DJU 16.8.2004). Em sentido semelhante: "A pena de perdimento não alcança quem adquiriu a mercadoria estrangeira, no mercado interno, de comerciante estabelecido, mediante nota fiscal. O comprador de mercadoria exposta em loja sujeita a fiscalização, não pode ser obrigado a investigar o modo como ela entrou no país. A pena de perdimento - até por ser pena — não pode abstrair do elemento subjetivo nem desprezar a boa-fé" (REsp. n 79.764/DF, DJU 17.6.1996). No corpo deste último acórdão há referência a outros julgados que trilharam o mesmo caminho (REsp. $\mathrm{n}^{\circ}$ 11.137/PE, DJU 6.11.1995; REsp. no 23.513/RJ, DJU 8.11.1993; REsp. no 15.073/DF, DJU 15.8.1994). Em sentido contrário, ver REsp. n 51.267-0/SP, RSTJ 69/475.

64 "Exclui-se como requisito necessário a culpabilidade para integração do tipo punível de caráter administrativo. (...) Basta para tipificação de certas infrações a voluntariedade (entendida aqui não como mero ânimo - e, pois, etapa pré-jurídica do comportamento - mas o impulso anímico gerador de efeitos jurídicos); basta o comportamento desconforme ao comportamento exigido" (Infrações e Sanções Administrativas, p. 8).

65 "Concluindo, ao menos em termos de ilícito administrativo, diferentemente do que ocorre com o direito penal, não há que se reportar a culpabilidade e, como conseqüência disso, a punibilidade. Ou há ilícito (e nele pode estar o elemento subjetivo como necessário, como conditio sine qua non) e deve-ser a sanção , ou não há: tertium non datur" (Sanções Administrativas, p. 66).

66 "É de meridiana evidência que descaberia qualificar alguém como incurso em infração quando inexista a possibilidade de prévia ciência e prévia eleição, in concreto, do comportamento que o livraria da incidência na infração e, pois, na sujeição às sanções para tal caso previstas. Note-se que aqui não se está a falar de culpa ou dolo, mas de coisa diversa: meramente do animus de praticar dada conduta" (Curso de Direito Administrativo, p. 751)

67 Op. e loc. citados.
}

A \& C R. de Dir. Administrativo e Constitucional, Belo Horizonte, ano 5, n. 22, p. 25-57, out./dez. 2005 
de impulsos involuntários. Não há decisão: o evento ocorre a despeito da vontade humana.

Todavia, com o respeito devido aos autores que entendem de modo distinto, apenas a voluntariedade não é suficiente para a configuração de ilícito administrativo. É certo que a voluntariedade é indispensável, pois sem ela não há que se falar sequer em ação. ${ }^{69}$ Mas uma conduta humana pode ser voluntariamente voltada a um resultado lícito e atingir, não obstante, resultado ilícito, mesmo com a adoção de todas as precauções para que não ocorra esse desvio. Em outras palavras: agindo voluntariamente, com toda diligência exigida de um homem comum e desejando atingir resultado lícito, um indivíduo pode acabar produzindo como resultado um evento tipificado como infração administrativa. Não parece adequada a imposição de sanção nesta última hipótese.

Só a característica da voluntariedade indica muito pouco sobre a conduta humana, sendo acertada a opinião de Rebollo Puig, para quem a mera voluntariedade "poco interés práctico tiene para las infracciones administrativa". ${ }^{70}$ Com voluntariedade, um sujeito pode: i) praticar um ilícito administrativo porque assim desejou (dolo); ii) praticá-lo não por tê-lo desejado mas sim por não ter tomado as precauções exigidas pela situação (culpa stricto sensu); iii) praticar uma infração sem desejá-la e a despeito de ter agido com a diligência necessária para evitá-la (apenas voluntariedade). São três comportamentos muito distintos, que bem por isso não podem receber do ordenamento jurídico o mesmo tratamento. ${ }^{71}$

Ademais, é a ocorrência das duas primeiras condutas acima referidas que o ordenamento jurídico pretende prevenir ao criar infrações e sanções administrativas. A terceira não, pois nela nada há de inadequado: o particular não quis praticar a infração, tendo voluntariamente agido para atingir fim lícito; o particular tampouco deixou de observar a diligência exigida, atuando com cuidado e precaução. Nada há a prevenir

\footnotetext{
${ }^{68}$ Como ensina Manuel Rebollo Puig, entendida em sentido estrito a voluntariedade só falta "cuando el sujeto queda paralizado, en los estados de inconsciencia, cuando concurre fuerza irrestible o se obra por movimientos reflexos" (El Derecho Administrativo Sancionador, p. 287). Luiz Regis Prado cita como exemplos de ausência de ação a convulsão epilética (ato reflexo), a vis absoluta ("obrigar fisicamente o coagido a golpear") e morte causada por atropelamento em virtude de defeito mecânico do veículo (caso fortuito). Em todos os exemplos, a ação ocorre independentemente da vontade do agente (Curso de Direito Penal Brasileiro, p. 265-266).

69 "Para la existencia de acción es necesario que el origen de la conducta externa, activa u omisiva, sea resultado de una previa decisión" (TESO, Ángeles de Palma Del. El Principio de Culpabilidad en el Derecho Administrativo Sancionador, p. 122).

70 Op. cit., p. 287.

${ }^{71}$ Daí afirmar Luiz Regis Prado que o princípio da culpabilidade tem também por fundamento o princípio da isonomia, "que veda o mesmo tratamento ao culpável e inculpável" (op. cit., p. 117).
} 
em caso semelhante.

Retorne-se ao exemplo ao início utilizado. Combinados, os arts. 162, inciso I e 163 do Código Brasileiro de Trânsito (Lei no 9.503/1997) tipificam como infração administrativa a conduta "entregar a direção de veículo a pessoa sem habilitação”. Pretende o diploma legal evitar duas condutas: i) alguém entregar, com consciência e vontade, a direção de veículo a quem não seja portador de $\mathrm{CNH}$, ou ii) alguém entregar, por negligência, a direção de veículo a pessoa sem habilitação. No primeiro caso há dolo, no segundo culpa stricto sensu. Se o evento típico "entregar a direção de veículo a pessoa sem habilitação" foi alcançado sem dolo ou culpa, mas apenas com voluntariedade - no caso de apresentação de CNH falsificada, conforme exemplo antes utilizado —, razão alguma há para a imposição da sanção administrativa, pois não foram praticadas as condutas cuja observância o legislador deseja prevenir. É dizer, o comportamento adotado pelo particular não é o que se pretende prevenir com a sanção.

Em suma, a sanção administrativa retributiva aplicada a sujeito que agiu sem dolo ou culpa, mas apenas com voluntariedade, não vai atingir seu fim preventivo, mostrando-se inadequada e, portanto, ofensiva ao princípio constitucional da proporcionalidade.

\subsection{Pessoalidade e intransmissibilidade da sanção administrativa}

Decorrência lógica e necessária da culpabilidade, o princípio da pessoalidade da sanção administrativa veda a imposição ou transmissão da medida sancionadora a terceiros que não participaram da conduta típica. ${ }^{72}$ Em poucas palavras: a sanção deve ser imposta tão-somente a quem, com dolo ou culpa stricto sensu, realiza a infração administrativa, sendo vedada a punição por fato de outrem.

O princípio da pessoalidade está expressamente previsto na Constituição Federal de 1988, que em seu art. $5^{\circ}$, inciso XLV assegura que "nenhuma pena passará da pessoa do condenado". Não há no referido dispositivo constitucional qualquer elemento que indique estar sua apli-

\footnotetext{
72 Ressaltando a ligação entre culpabilidade, pessoalidade e intransmissibilidade da sanção administrativa, Pasquale Cerbo ensina: "il principio di intrasmissibilità opera pienamente: I'obbligazione pecuniaria non si trasmette agli eredi. In tal modo il principio di intrasmissibilità diviene un corollario del principio della personalità dell'obbligazione susseguente ad irrogazione di sanzione amministrativa, che trova, del resto, conferma anche nel nesso di colpevolezza (nella forma del dolo o della colpa) che debe unire il fatto al suo autore nell'illecito amministrativo, salvo alcune eccezioni" (Le Sanzioni Amministrative, p. 39).
} 
cação limitada à esfera do direito penal, cabendo lembrar ainda que se trata de garantia constitucional individual, cuja interpretação deve ser a mais abrangente possível, por força do princípio da máxima efetividade. ${ }^{73}$ Vale mencionar que sob a égide da Constituição Federal de 1967, Régis Fernandes de Oliveira sustentava que dispositivo semelhante ao acima referido (art. 153, § 13 ${ }^{\circ}$ ) tinha aplicação no direito administrativo sancionador, de modo que as sanções administrativas retributivas "aplicam-se apenas ao próprio infrator, em obediência ao princípio mencionado”. ${ }^{74}$

Mas mesmo que nada dispusesse o texto constitucional, ainda assim teria aplicação no direito administrativo sancionador o princípio da pessoalidade da sanção, que nada mais é do que um corolário lógico do princípio da culpabilidade. De fato, sendo aceito o princípio da culpabilidade em seu sentido mais evidente, que exige a atuação dolosa ou culposa como condição à imposição de sanção administrativa retributiva, não há como não aceitar a incidência do princípio da pessoalidade da sanção no direito administrativo sancionador. Se a sanção somente pode ser aplicada ao indivíduo que age com dolo ou culpa, a terceiro que não contribuiu para a ocorrência da infração, e portanto não agiu com dolo ou culpa, não pode ser imposta medida sancionadora.

Ademais, a imposição ou transmissão de sanção administrativa retributiva a terceiro que não praticou a conduta típica é medida manifestamente inadequada ao atendimento da finalidade preventiva vinculada à competência punitiva da Administração Pública. Foi já afirmado e repetido: a sanção administrativa tem por escopo prevenir a ocorrência de futuras infrações. Tal finalidade não é atingida se a sanção é imposta a pessoa que não praticou a conduta típica. ${ }^{75}$ Bem pelo contrário, a possibilidade de que a medida sancionadora seja imposta ou transmitida a terceiros serve como estímulo à prática da conduta, já que o infrator não estará sujeito às conseqüências negativas que advém da aplicação da sanção.

Sendo inadequada ao atendimento de sua finalidade preventiva, a sanção administrativa retributiva não pode ser imposta ou transmitida a

\footnotetext{
${ }^{73}$ CANOTILHO, José Joaquim Gomes. Direito Constitucional, p. 1.149.

${ }^{74}$ Infrações e Sanções Administrativas, p. 15. Já sob a vigência do atual texto constitucional, ensina Fábio Medina Osório: "A pena criminal somente pode atingir o sentenciado (art. 5 $, \mathrm{XLV}, \mathrm{CF}$ ), exigência que me parece incidente no campo do Direito Administrativo Sancionador. A pena administrativa somente pode atingir a pessoa sancionada, o agente efetivamente punido, não podendo ultrapassar de sua pessoa" (op. cit., p. 340). Em sentido contrário, ver FERREIRA, Daniel, op. cit., p. 71-76; VITTA, Heraldo Garcia, p. 119-122.
} 
terceiro que não praticou a conduta típica. ${ }^{76}$

\subsection{O erro no direito administrativo sancionador. O erro de tipo}

A adoção do princípio da culpabilidade no âmbito do direito administrativo sancionador torna relevante a figura do erro. Afinal, como bem lembra Régis Fernandes de Oliveira, "o erro pode eliminar o elemento subjetivo e excluir a culpa". ${ }^{77} \mathrm{Em}$ certas circunstâncias o erro afasta o dolo ou mesmo a culpa stricto sensu do agir do particular, tornando descabida a imposição da sanção administrativa.

Para Luiz Regis Prado, erro é "uma falsa noção ou um falso conhecimento de um fato ou de uma regra jurídica". ${ }^{78}$ Trata-se de percepção equivocada sobre algo. $\mathrm{O}$ indivíduo que incide em erro tem uma percepção distorcida da realidade: considera que conhece ou compreende determinado objeto, mas não o conhece nem compreende de modo correto. A noção que tem o indivíduo de certo objeto não corresponde à realidade. Por força de sua percepção distorcida, o particular pode praticar uma conduta típica. Resta saber se o erro que motivou o particular a adotar comportamento proibido é ou não relevante para o ordenamento jurídico. Para tanto, convém que se diferenciem duas situações: o erro de tipo e o erro de proibição.

O erro de tipo consiste em falsa percepção sobre algum elemento da conduta típica praticada pelo agente: "tem-se um erro sobre elementos ou circunstâncias do tipo”, explica Assis Toledo. ${ }^{79} \mathrm{O}$ indivíduo pratica uma conduta mas imagina estar praticando outra, sendo o erro essencial para o desvio entre o comportamento praticado e o desejado. Em poucas palavras: ocorrendo erro de tipo, "o agente não sabe o que está fazendo", na sucinta e clara lição de Luiz Regis Prado. ${ }^{80}$

75 "La inaplicación del principio de personalidad de las sanciones conduce a desvirtuar la finalidad de prevención que el Derecho Sancionador Administrativo está llamado a cumplir. La sanción debe recaer sobre aquellos que hayan tenido alguna participación en los hechos constitutivos de infracción, de otro modo no sería posible adaptarla a las circunstancias objetivas y subjetivas que rodean el hecho, y dar así cabal cumplimiento a la finalidad de prevención general y especial" (TESO, Ángeles de Palma Del, op. cit., p. 78).

76 Tal posição já foi adotada pelo Supremo Tribunal Federal, que entendeu não serem as multas fiscais punitivas transmissíveis aos sucessores do infrator, ao contrário do que ocorre com os tributos. É o que consta do seguinte julgado, da lavra de Aliomar Baleeiro: "O art. 133 do CTN responsabiliza solidariamente o sucessor do sujeito passivo pelos tributos que este não pagou, mas não autoriza a exigência de multas punitivas, que são de responsabilidade pessoal do antecessor" (RE $n^{\circ} 76.153 / S P, R T J 69 / 211$ ). No mesmo sentido, ver RTJ 74/139, 74/748, 77/457, 82/544, 87/230, 94/758 e 98/733.

77 Op. cit., p. 48. Ressalte-se que o referido autor não entende que a culpabilidade seja sempre relevante no campo do direito administrativo sancionador, contentando-se com a mera voluntariedade, como visto acima. A relevância do erro, para Régis Fernandes de Oliveira, ocorre apenas "nas infrações que são praticadas com a consideração do elemento subjetivo (culpabilidade)" (id., ibid.). Ainda sobre a relação entre erro e culpabilidade, transcreva-se a lição de Ángeles de Palma Del Teso: "La absoluta erradicación de la responsabilidad objetiva y la consiguiente exigencia de culpa o dolo conllevan la relevancia del error" (op. cit., p. 159).

${ }^{78}$ Curso de Direito Penal Brasileiro, p. 358.

A \& C R. de Dir. Administrativo e Constitucional, Belo Horizonte, ano 5, n. 22, p. 25-57, out./dez. 2005 
Cite-se o exemplo clássico do direito penal: alguém subtrai coisa alheia (furto) imaginando ser dela proprietário. Em tal situação o erro recai sobre elemento do tipo: ser alheia a coisa. Foi praticada a conduta típica (subtrair coisa alheia), mas em função de falsa percepção do agente sobre elemento essencial do tipo, a propriedade do bem, já que imaginava ser sua a coisa subtraída. Ou ainda: determinada pessoa utiliza produto agrotóxico imaginando que em sua composição não há a substância proibida X, cujo uso constitui infração administrativa. A conduta típica (utilizar a substância X) foi praticada em virtude do erro acerca da composição do produto empregado.

O erro de tipo afasta o dolo, já que o agente pratica a conduta típica sem desejá-la. Mas nem sempre o erro de tipo afasta a culpa stricto sensu, pois a falsa percepção sobre elemento da conduta pode ter sido causada por negligência, imperícia ou imprudência do agente. ${ }^{81}$ Todavia, sendo o erro inevitável, considerando-se o dever de diligência exigido na situação concreta, não há que se falar sequer em culpa. Em tal hipótese, não há infração administrativa e não pode ser imposta a sanção. ${ }^{82}$

Retome-se o exemplo acima utilizado. Uma pessoa não sabia que o produto agrotóxico utilizado continha a substância proibida X, cujo uso constituía infração administrativa. Se não sabia porque não lera a embalagem da qual constava expressamente a informação, o erro era evitável e ocorreu em virtude de negligência. Em tal hipótese há infração administrativa e deve ser imposta a respectiva sanção. Se não sabia porque a substância X não constava do rol de elementos mencionados na embalagem do agrotóxico utilizado, o erro era inevitável. Não há nem mesmo culpa stricto sensu, pois o dever de diligência exigido em situação semelhante foi cumprido: verificar a composição do produto antes de utilizá-lo. ${ }^{83}$

\subsection{0 erro de proibição}

A outra espécie de erro não diz respeito aos elementos da figura

\footnotetext{
79 Princípios Básicos de Direito Penal, p. 267.

${ }^{80}$ Op. cit., p. 361.

${ }^{81}$ Daí a disposição do art. 20 do Código Penal: "o erro sobre elemento constitutivo do tipo legal de crime exclui o dolo, mas permite a punição por crime culposo, se previsto em lei".

82 "Si el error en que se ha incurrido fuera vencible, esto es, hubiera podido evitarse observando el debido cuidado, estaríamos ante un error imprudente, que excluiría el dolo pero no la imprudencia. Sin embargo, si el error fue invencible, esto es, no hubiera podido evitarse aun con una conducta diligente, excluiría tanto el dolo como la imprudencia" (TESO, Ángeles de Palma Del. El Principio de Culpabilidad en el Derecho Administrativo Sancionador, p. 158).
} 
típica, tal qual ocorre com o erro de tipo, mas sim à licitude da conduta. A pessoa tem plena consciência da conduta que adota, mas erroneamente considera que sua prática é permitida pelo ordenamento jurídico. A falsa percepção tem por objeto a proibição, que o agente considera não existir. Supõe o indivíduo estar praticando conduta lícita, quando na realidade está adotando comportamento tipificado como infração administrativa. Em tal situação há erro de proibição. ${ }^{84}$

O erro de proibição incide sobre o ordenamento jurídico. Por força de um conhecimento errôneo das normas jurídicas, o agente pratica a infração imaginando que não está atuando de modo ilícito. Há uma falsa percepção acerca da permissão para a adoção de certo comportamento: age o particular com a errônea convicção de estar praticando conduta permitida pelo ordenamento jurídico.

É certo que "ninguém se escusa de cumprir a lei, alegando que não a conhece", ${ }^{85}$ mas é preciso admitir que há situações em que é inevitável o erro acerca do tratamento jurídico que certa conduta recebe no âmbito do sistema normativo. O problema é especialmente tormentoso no direito administrativo sancionador, em que, ao contrário do que usualmente ocorre no direito penal, as condutas típicas não são comportamentos tidos como imorais e reprováveis pela sociedade, tendo isso sim relação com a inobservância de deveres dos particulares em face da própria Administração Pública ou com o exercício de certas atividades disciplinadas pelo Estado. Cabe aqui a advertência de Quintero Olivares, para quem "respecto de las infracciones administrativas no es razonable suponer un conocimiento ‘profano' o 'intuitivo”" ${ }^{86}$ De modo mais ilustrativo: saber que matar alguém é conduta ilícita não depende de conhecimentos técnicos, sendo intuitiva a compreensão da ilicitude de tal conduta. Mas saber que a utilização do produto agrotóxico $\mathrm{X}$ ou Y é proibida já demanda outro tipo de conhecimento, técnico e não intuitivo.

\footnotetext{
${ }^{83}$ Veja-se o seguinte julgado do TRF da $4^{a}$ Região, que reconhece erro de tipo praticado pelo agente: "Tributário. Retirada de container carregado e tido como vazio. Apreensão. Pena de perdimento. A responsabilidade objetiva a que se refere o art. 136 do CTN/66 não tem o alcance de enquadrar situações em que a conduta do agente desvia-se do padrão por equivocada percepção da realidade, de modo involuntário, pois nesse caso não se cogita da intenção" (REO 96.04.60806-1/RS, DJU 1.10.1997, p. 80.644).

84 "Há erro de proibição quando o agente supõe, por erro, ser lícito o seu comportamento" (FRAGOSO, Heleno Cláudio, op. cit., p. 205). Ou ainda: "trata-se de erro que tem por objeto a proibição jurídica do fato. É dizer: o agente perde, em decorrência do erro de proibição, a compreensão da ilicitude do fato. Constitui o lado oposto da consciência do injusto: supõe erroneamente que atua de forma lícita, conforme a norma" (PRADO, Luiz Regis, op. cit., p. 363).

${ }^{85}$ Lei de Introdução ao Código Civil Brasileiro (Decreto-lei n 4.657/1942), art. 3º. Disposição semelhante consta do art. 21 do Código Penal: "o desconhecimento da lei é inescusável".
} 
O excesso de leis e regulamentos que disciplinam a atuação da Administração Pública dificulta ainda mais o conhecimento dos diversos deveres e obrigações que são impostos pelos entes estatais, cuja inobservância pode conduzir à imposição de sanção administrativa. Tal situação pode levar o particular a agir com erro acerca da licitude de sua conduta, já que "en la actualidad resulta materialmente imposible que el ciudadano conozca todos los mandatos y prohibiciones que le rodean y que le convierten en un infractor no sólo potencial sino real", como afirma Alejandro Nieto. ${ }^{87}$

O erro de proibição, se inevitável, afasta a culpabilidade do agente e torna incabível a imposição da sanção administrativa. Para tanto, é preciso que o erro de proibição tenha ocorrido apesar do atuar diligente do indivíduo na busca da correta compreensão das normas jurídicas. Não basta o particular invocar o desconhecimento da lei para que o erro de proibição seja considerado como causa de isenção de culpa. É preciso mais: deve o particular demonstrar que tentou, com a diligência exigida pela situação, conhecer o tratamento jurídico atribuído à conduta que pretendia praticar. No dizer de Ignacio Pemán Gavín, “el error únicamente podrá concurrir cuando haya existido una actuación diligente por parte del autor a fin de conocer la situación antijurídica”. Dito de outro modo: para a configuração de erro de proibição apto a isentar de culpa o agente, é necessário que este tenha "los conocimientos que le son exigibles". 88

Cabe notar que o grau de diligência exigido varia conforme a atividade desenvolvida pelo particular que pratica a infração administrativa, se profissional ou não. ${ }^{89}$ Sendo a norma dirigida à generalidade das pessoas, a todos os integrantes do grupo social, a diligência que se pode exigir é a adotada pelo homem comum, prudente e normal. A situação é distinta se a norma jurídica impõe obrigação ou proibição no âmbito de certa atividade profissional, sendo plenamente exigível dos profissionais que a exercem o pleno conhecimento da sua disciplina jurídica. Uma pessoa que atue profissionalmente em certa área não pode invocar desconhecimento das normas que a disciplinam, pois a diligência dela exigível é a de conhecer todas as

\footnotetext{
${ }^{86}$ La Autotutela, los Limites al Poder Sancionador de la Administración Publica y los Principios Inspiradores del Derecho Penal, p. 269.

87 Para Nieto, "no existe ni un solo individuo que pueda alardear de no estar infringiendo un deber administrativo, hasta tal punto que el ser sancionado, o no, depende del azar y de la diligencia de los funcionarios. En estas circunstancias, exigir el conocimiento de las leyes (en sentido amplio) no es un formalismo: es un escarnio" (Derecho Administrativo Sancionador, p. 370).

${ }^{88}$ El Sistema Sancionador Español, p. 317.
}

A \& C R. de Dir. Administrativo e Constitucional, Belo Horizonte, ano 5, n. 22, p. 25-57, out./dez. 2005 
normas que se aplicam à sua atividade profissional.

Assim, se um profissional, no âmbito de sua atividade, pratica infração administrativa por erro de proibição, em regra terá agido com culpa. ${ }^{90}$ Se a pessoa age com culpa, descumprindo o dever de diligência que lhe foi imposto ao ingressar em determinado campo profissional, deve sofrer os efeitos negativos da sanção administrativa.

O erro de proibição pode ser causado pela obscuridade ou contradição das normas jurídicas. A segurança jurídica é um dos corolários do princípio fundamental do Estado de Direito, exigindo que as normas jurídicas sejam claras e precisas, de modo que os particulares saibam exatamente o comportamento que lhes é imposto ou proibido pelo ordenamento jurídico. ${ }^{91}$

Se a norma jurídica é obscura ou contraditória, permitindo mais de uma interpretação razoável, o erro de proibição é inevitável..$^{92} \mathrm{O}$ particular, atuando de modo diligente, procura saber se a conduta que deseja praticar é ou não permitida pelo ordenamento jurídico, mas encontra resposta obscura e dúbia. Em tal situação, o erro de proibição não decorre de culpa do agente, não sendo cabível a imposição da sanção administrativa.

Pode ainda o erro de proibição ser causado pela atuação da própria Administração Pública. O agir dos entes administrativos pode contribuir para tornar obscura e contraditória a interpretação das normas jurídicas. Imagine-se regulamento administrativo que contradiga o disposto em

\footnotetext{
89 Para Alejandro Nieto, "En el campo del Derecho Administrativo Sancionador resulta de ordinario trascendental el hecho de que el infractor sea un profesional o un lego" (op. cit., p. 364). Em sentido semelhante, Fábio Medina Osório ensina: "Diga-se que somente o erro inevitável, invencível, há de ser eficaz no Direito Administrativo Sancionador, sendo que o grau de exigência — para o reconhecimento dessa modalidade exculpatória - é tanto maior quanto o sejam as qualidades profissionais do agente, o qual passa a ter um dever de conhecimento de determinadas circunstâncias normativas" (op. cit., p. 338).

90 É a opinião de Emilio Rosini, para quem um indivíduo "professionalmente inserito in un determinato campo di attività, non può ignorarne senza colpa le regole peculiari" (Le Sanzioni Amministrative, p. 65). Ver ainda a lição de Alejandro Nieto: "cuando la infracción ha sido cometida en el ejercicio de una profesión o actividad especializada se esfuma la posibilidad de error porque — por así decirlo — la norma ha impuesto la obligación de no equivocarse y opera, en consecuencia, la presunción de que no se ha equivocado. El profesional ha adquirido - a través de los estudios que preceden a su título oficial — una formación técnica que le preserva (formalmente) contra el error, y quien ejerce una actividad especializada está obligado a adoptar precauciones especiales para evitarlo y hasta es frecuente que la norma le exija que con él colaboren profesionales y expertos" (op. cit., p. 364). No mesmo sentido, TESO, Ángeles de Palma Del. El Principio de Culpabilidad en el Derecho Administrativo Sancionador, p. 172-173.

91 "L'esigenza di certezza delle norme, e attraverso di essa, del diritto, è fatto essenziale per una convivenza ordinata: sulla certezza si fonda la sicurezza dell'individuo. Ciascuno deve poter sapere, concepita un'azione, come l'azione stessa è qualificata dall'ordinamento. L'approfondimento di questa esigenza ha portato ad enucleare i caratteri, il contenuto; e su questo piano si è detto che la certezza si concreta nella precisione, nella fissità della norma" (SINISCALCO, Marco. Depenalizzazione e Garanzia, p. 158).

92 "A obscuridade, confusão ou complexidade das leis tributárias são circunstâncias que a jurisprudência vem contemplando como justificadoras de erro no devido cumprimento das obrigações fiscais. Assim, tem-se
} 
lei formal. Parece óbvio que não se pode impor sanção administrativa a particular que, por seguir fielmente disposição regulamentar, pratica conduta tipificada por lei formal. O erro de proibição aqui é plenamente justificável, não se podendo falar em culpa do indivíduo. ${ }^{93}$

O erro de proibição pode ainda ser derivado de informações equivocadas prestadas pela Administração Pública, que indiquem ao particular um modo de agir que se revele ilícito. O particular, em dúvida acerca da licitude de certa conduta, formula consulta ou pede informações à Administração Pública, recebendo resposta errada. O dever de diligência exigido do particular foi cumprido, na medida em que foram adotadas providências para afastar a dúvida acerca do tratamento jurídico que determinado comportamento recebe no sistema. Se a resposta da Administração Pública leva o particular a incidir em erro, praticando conduta típica em face da equivocada informação prestada pelo agente administrativo, não há espaço para a imposição de sanção, já que não há culpa em situação semelhante. O Supremo Tribunal Federal já acolheu tal entendimento, afastando multa fiscal por considerar que a contribuinte "em erro fora induzida pela resposta da autoridade fiscal à sua consulta". ${ }^{94}$

As práticas reiteradas da Administração Pública também podem induzir em erro de proibição o particular. Decisões administrativas reiteradamente adotadas pelos órgãos administrativos geram nos particulares a convicção de que representam entendimento conforme o direito positivo, não sendo culpável o agir do indivíduo que segue a orientação nelas adotada. Bem por isso, a mudança de orientação consolidada por seguidas decisões da Administração não pode se voltar para o passado, mas apenas para o futuro. Se a Administração muda seu entendimento acerca da legalidade de certa conduta, não pode impor sanção administrativa aos particulares que se pautaram pelo entendimento anterior, pois

decidido que 'se a obscuridade da lei tributária houve de induzir em erro o contribuinte, justifica-se exonerálo de responsabilidades'. Em outro caso admitiu-se o erro quando o texto da lei tornava possível equívocos interpretativos. Igualmente, tem-se afirmado que quando a lei, ou as normas de aplicação, vêm sofrendo uma série de variações suscetíveis de produzir dúvidas, é admissível o erro escusável, assim como pode darIhe lugar, o fato de que a lei possa ser objeto de interpretações contraditórias na doutrina e na jurisprudência" (VILLEGAS, Hector. Direito Penal Tributário, p. 269-270).

93 "También se considera error inducido por la Administración aquél provocado por disposiciones administrativas de carácter general. Cuando un Reglamento dictado para la interpretación de una norma con rango de ley contradiga a ésta, si el ciudadano se conduce conforme a lo dispuesto en la norma interpretativa no es posible considerar antijuridica su conducta y sancionarla" (TESO, Ángeles de Palma Del, op. cit., p. 168).

${ }^{94}$ RE no 62.782/SP, RTJ 46/202. Ruy Barbosa Nogueira segue a mesma linha, como se lê: "não pode o contribuinte ser punido quando agiu baseado em instrução ou informação da autoridade competente" (Curso de Direito Tributário, p. 199). 
agiram sem culpa alguma. ${ }^{95}$

E mesmo a omissão da Administração pode conduzir à errônea impressão de ser lícita determinada conduta típica. É que os agentes administrativos, ao tolerarem a prática de certo comportamento por período de tempo prolongado, geram a impressão de se tratar de comportamento permitido pelo ordenamento jurídico. Nas palavras de Jesús Gonzáles Pérez, tal tolerância pode levar à idéia de consentimento, idéia que "puede aminorar, incluso eventualmente excluir, la entrada en juego del elemento básico de la infracción que es la imputabilidad y dolo o culpa". ${ }^{96}$

Enfim, i) a edição de regulamentos obscuros e contraditórios, ii) a prestação de informações equivocadas, iii) a prática reiterada de decisões e atos, mesmo omissivos, iv) a tolerância com certos comportamentos, são atividades da Administração Pública que podem gerar erro de proibição invencível, tornando incabível a imposição de sanção administrativa.

No âmbito tributário, convém salientar, os fatos acima arrolados são reconhecidos como causadores de erro de proibição, tornando o particular isento de culpa pela prática do ilícito tributário. De fato, o Código Tributário Nacional dispõe em seu art. 100 que "exclui a imposição de penalidades" a observância, pelo contribuinte, i) de "atos normativos expedidos pelas autoridades administrativas", ii) de "decisões dos órgãos singulares ou coletivos de jurisdição administrativa”, bem como iii) de "práticas reiteradamente observadas pelas autoridades administrativas". ${ }^{97}$

\section{Conclusão}

No direito administrativo sancionador deve ser observado o princípio da culpabilidade, que veda a imposição de sanção administrativa retributiva a sujeito que agiu sem dolo ou culpa stricto sensu. É que em tais casos a medida sancionadora não é idônea à satisfação de sua finalidade

\footnotetext{
${ }_{95} \mathrm{O}$ mesmo entendimento pode ser aplicado à hipótese em que se altera jurisprudência consolidada em tribunais, mormente quando se tratem de tribunais superiores. Em parecer que analisa o tema, Clèmerson Merlin Clève, reconhecendo que "a jurisprudência presta-se a orientar a conduta do Poder Público (aqui, inclusive, do Judiciário) e dos particulares", conclui: "se a administração tributária, com base em jurisprudência, costumava considerar reiteradamente certa subvenção fiscal lícita e legítima (caso de créditoprêmio do (PI), reconhecendo-a de forma estável, não pode, em face de alteração jurisprudencial que a considere ilegítima, pretender buscar ressarcimento de montantes já utilizados ou liberados aos contribuintes. A modificação da jurisprudência, assim, poderá orientar a sua atuação futura, diante da demanda de calculabilidade e previsibilidade, mas jamais alcançar o passado" (Crédito-prêmio do IPI. Eventual Mudança de Orientação Jurisprudencial e Princípio Constitucional da Segurança Jurídica, p. 178-179).

${ }^{96}$ El Principio General de la Buena Fe en el Derecho Administrativo, p. 163. No mesmo sentido, Carlo Enrico Paliero e Aldo Travi sustentam que não é culpável o agir ilícito adotado "in conformità di una prassi costante suggeritta o tollerata dalle autorità preposte alla disciplina o al controllo di certe attività" (La Sanzione Amministrativa, p. 202)
} 
preventiva, ferindo o princípio da proporcionalidade.

O princípio da culpabilidade tem como corolário o princípio da pessoalidade da sanção administrativa retributiva, que veda a imposição ou transmissão da medida sancionadora a terceiros que não participaram da conduta típica. A sanção administrativa retributiva deve ser imposta tão-somente a quem, com dolo ou culpa stricto sensu, realiza a infração administrativa, sendo vedada a punição por fato de outrem.

A adoção do princípio da culpabilidade no direito administrativo sancionador torna relevante a figura do erro, que sendo invencível afasta a culpa do agente e torna descabida a sanção administrativa.

\section{Referências bibliográficas}

ALESSI, Renato. Responsabilità Amministrativa. In: Novissimo Digesto Italiano. Torinese, 1957 , v. XV.

ALESSI, Renato. Principi di Diritto Amministrativo. 3. ed. Milão: Giuffrè, 1974, v. I.

ATALIBA, Geraldo. Imposto de Renda - Multa Punitiva. Revista de Direito Administrativo, Rio de Janeiro, v. 126, p. 547-557, out./dez. 1976.

ATALIBA, Geraldo. Inconstitucionalidade de Sanções Permanentes. Revista de Direito Mercantil, Industrial, Econômico e Financeiro, São Paulo, n. 95, p. 15-25, jul./set. 1994.

BANDEIRA DE MELlO, Celso Antônio. Curso de Direito Administrativo. 17. ed. São Paulo: Malheiros, 2004.

BAQUER, Lorenzo Martín-Retortillo. Multas Administrativas. Revista de Administración Pública, Madri, v. 79, p. 9-65, jan./abr. 1976.

BATTAGLINI, Giulio. La Pena in Raporto alle Sanzioni Civili ed Amministrative. Rivista di Diritto Pubblico, Roma, p. 394-412, 1924.

BÉNOIT, Francis-Paul. Le Droit Administratif Français. Paris: Dalloz, 1968.

BERLIRI, Giuseppe. Sanzioni Amministrative e Principi Costituzionali della Potestá Punitiva Penale. In: Le Sanzioni Amministrative: atti del XXVI Convegno di Studi di Scienza Dell'amministrazione. Milão: Giuffrè, 1982, p. 285-303.

BETTIOL, Giuseppe. Direito Penal. Trad. Paulo José da Costa Júnior e Alberto Silva Franco. São Paulo: Revista dos Tribunais, 1966, v. I.

BIM, Eduardo Fortunato. A Inconstitucionalidade da Responsabilidade Objetiva no Direito

\footnotetext{
${ }^{97}$ Fortunato Bim, em defesa da tese da subjetividade da responsabilidade no direito tributário sancionador, questiona com propriedade acerca do art. 100 do CTN: "se o fisco pode errar por que não o pode também o contribuinte? E mais, em que ponto a ilegal aplicação da legislação tributária pelo Fisco se diferencia da sua não-aplicação por ignorância ou outro motivo qualquer pelo contribuinte? Se na aplicação da norma tributária (já que todas as situações tratadas no art. 100 são aplicações, mesmo abstratas, como são os atos normativos, da lei tributária) é reconhecida ao fisco a possibilidade de errar, também deve-se reconhecer tal direito ao contribuinte, desde que não esteja presente a má-fé. O imperativo constitucional da isonomia impõe tal exegese" (A Inconstitucionalidade da Responsabilidade Objetiva no Direito Tributário Sancionador, p. 161).
} 
Tributário Sancionador. Revista dos Tribunais. São Paulo, v. 788, p. 143-169, jun. 2001.

BONAVIDES, Paulo. Curso de Direito Constitucional. 5. ed. São Paulo: Malheiros, 1994.

CANOTILHO, José Joaquim Gomes. Direito Constitucional. 3. ed. Coimbra: Almedina, 1999.

CARVALHO, Paulo de Barros. Curso de Direito Tributário. 10. ed. São Paulo: Saraiva, 1998.

CARVALHOSA, Modesto; EIZIRIK, Nelson. A Nova Lei das S/A. São Paulo: Saraiva, 2002.

CERBO, Pasquale. Le Sanzioni Amministrative. Milão: Giuffrè, 1999.

CINTRA, Carlos César Sousa. Reflexões em Torno das Sanções Administrativas Tributárias. In: MACHADO, Hugo de Brito (Coord.). Sanções Administrativas Tributárias. São Paulo: Dialética, 2004, p. 54-98.

CLÈVE, Clèmerson Merlin. Crédito-prêmio do IPI. Eventual Mudança de Orientação Jurisprudencial e Princípio Constitucional da Segurança Jurídica. Revista dos Tribunais, São Paulo, v. 831, p. 165-184, jan. 2005.

COÊLHO, Sacha Calmon Navarra. Teoria e Prática das Multas Tributárias. 2. ed. Rio de Janeiro: Forense, 1998.

COÊLHO, Sacha Calmon Navarra. Manual de Direito Tributário. Rio de Janeiro: Forense, 2000.

DEL TESO, Ángeles de Palma. El Principio de Culpabilidad en el Derecho Administrativo Sancionador. Madri: Tecnos, 1996.

DELMAS-MARTY, Mireille; TEITGEN-COLLY, Catherine. Punir sans Juger? De la Répression Administrative au Droit Administratif Pénal. Paris: Economica, 1992.

DOTTI, René Ariel. Curso de Direito Penal - Parte Geral. Rio de Janeiro: Forense, 2001.

EIZIRIK, Nelson. Reforma das S/A e do Mercado de Capitais. 2. ed. Rio de Janeiro: Renovar, 1998.

ENTERRÍA, Eduardo García de. El Problema Jurídico de las Sanciones Administrativas. Revista española de derecho administrativo, Madri, v. 10, p. 399-430, jul./set. 1976 (no texto a referência de páginas é da versão eletrônica editada pela Civitas).

ENTERRÍA, Eduardo García de. Curso de Derecho Administrativo. 5. ed. Madri: Civitas, 1998, v. II.

FALLA, Fernando Garrido. Tratado de Derecho Administrativo. 2. ed. Madri: Instituto de Estudios Politicos, 1962, v. II.

FERREIRA, Daniel. Sanções Administrativas. São Paulo: Malheiros, 2001.

FRAGOSO, Heleno Cláudio. Lições de Direito Penal - A Nova Parte Geral. 4. ed. (atualizada por Fernando Fragoso). Rio de Janeiro: Forense, 1994.

FROMONT, Michel. République Fédérale d'Allemagne: L'État de Droit. Revue du Droit Public et de la Science Politique en France et a l'étranger. Paris, 1984, v. 1, p. 1.204-1.226.

GAVÍN, Ignacio Pemán. El Sistema Sancionador Español - Hacia una Teoría General de las Infracciones y Sanciones Administrativas. Barcelona: Cedecs, 2000.

GUERRA FILHO, Willis Santiago. Processo Constitucional e Direitos Fundamentais. São Paulo: Celso Bastos, 1999.

A \& C R. de Dir. Administrativo e Constitucional, Belo Horizonte, ano 5, n. 22, p. 25-57, out./dez. 2005 
GUERREIRO, José Alexandre Tavares. Sobre o Poder Disciplinar da CVM. Revista de Direito Mercantil, Industrial, Econômico e Financeiro. São Paulo, n. 43, p. 64-77, jul./set. 1981.

HESSE, Konrad. Elementos de Direito Constitucional da República Federal da Alemanha. Trad. Luís Afonso Heck. Porto Alegre: Sergio Antonio Fabris, 1998.

JAKOBS, Günther. Culpabilidad en Derecho Penal. Trad. Manuel Cancio Meliá e Marcelo A. Sancinetti. Bogotá: Universidad Externado de Colombia, 2003.

KELSEN, Hans. Teoria Pura do Direito. Trad. João Baptista Machado. 4. ed. Coimbra: Armênio Amado, 1979.

LAUBADÈRE, André de; VENEZIA, Jean-Claude; GAUDEMET, Yves. Traité de Droit Administratif. 14. ed. Paris: LGDJ, 1996, t. I.

MACHADO, Hugo de Brito. Teoria das Sanções Tributárias. In: MACHADO, Hugo de Brito (Coord.). Sanções Administrativas Tributárias. São Paulo: Dialética, 2004, p. 159-191.

MARTINS, Ives Gandra da Silva. Da Sanção Tributária. São Paulo: Saraiva, 1980.

MAS, Joaquín Tornos. Infracción y Sanción Administrativa: el Tema de su Proporcionalidad en la Jurisprudencia Contencioso-administrativa. Revista Española de Derecho Administrativo, Madri, v. 7, p. 607-624, out./dez. 1975 (no texto a referência de páginas é da versão eletrônica editada pela Civitas).

MATTÍN, Germán Valencia. Derecho Administrativo Sancionador y Principio de Legalidad. In: El Principio de Legalidad - Actas de las V Jornadas de la Asociación de Letrados del Tribunal Constitucional. Madri: Centro de Estudios Políticos y Constitucionales, 2000, p. 77-184.

MODERNE, Franck. Sanctions Administratives et Justice Constitutionnelle. Paris: Economica, 1993.

MUNHOZ DE MELLO, Rafael. Processo Administrativo, Devido Processo Legal e a Lei ${ }^{\circ}$ 9.784/99. Revista de Direito Administrativo, Rio de Janeiro, v. 227, p. 83-104, jan./mar. 2002.

NIETO, Alejandro. Derecho Administrativo Sancionador. 2. ed. Madri: Tecnos, 1993.

NOBRE JÚNIOR, Edilson Pereira. Sanções Administrativas e Princípios de Direito Penal. Revista de direito administrativo, Rio de Janeiro, v. 219, p. 127-151, jan./mar. 2000.

NOGUEIRA, Ruy Barbosa. Curso de Direito Tributário. 10. ed. São Paulo: Saraiva, 1990.

OLIVARES, Gonzalo Quintero. La Autotutela, los Limites al Poder Sancionador de la Administración Pública y los Principios Inspiradores del Derecho Penal. Revista de Administración Pública, Madri, n. 126, p. 253-293, set./dez. 1991.

OLIVEIRA, Régis Fernandes de. Infrações e Sanções Administrativas. São Paulo: Revista dos Tribunais, 1985.

OSÓRIO, Fábio Medina. Direito Administrativo Sancionador. São Paulo: Revista dos Tribunais, 2000 .

PALIERO, Carlo Enrico; TRAVI, Aldo. La Sanzione Amministrativa: Profili Sistematici. Milão: Giuffrè, 1988.

PELLICER, Angel Blasco. Sanciones Administrativas en el Orden Social. Valencia: Tirant lo Blanch, 1998.

PÉREZ, Adolfo Carretero; SANCHES, Adolfo Carretero. Derecho Administrativo Sancionador. Madri: Edersa, 1992.

A \& C R. de Dir. Administrativo e Constitucional, Belo Horizonte, ano 5, n. 22, p. 25-57, out./dez. 2005 
PÉREZ, Jesús González. El Principio General de la Buena Fe en el Derecho Administrativo. 3. ed. Madri: Civitas, 1999.

PONTES, Helenilson Cunha. O Princípio da Proporcionalidade e o Direito Tributário. São Paulo: Dialética, 2000.

PRADO. Luiz Regis. Curso de Direito Penal Brasileiro. 3. ed. São Paulo: Revista dos Tribunais, 2002 , v. I.

PUIG, Manuel Rebollo. El Derecho Administrativo Sancionador. In: MOREIRA NETO, Diogo de Figueiredo. Uma Avaliação das Tendências Contemporâneas do Direito Administrativo: Obra em Homenagem a Eduardo García de Enterría. Rio de Janeiro: Renovar, 2003, p. 263-313.

RINCÓN, José Suay. Sanciones Administrativas. Bolonha: Real Colegio de España, 1989.

ROSINI, Emilio. Le Sanzioni Amministrative. Milão: Giuffrè, 1991.

SANDUlLI, Aldo. La Proporzionalità dell'azione Amministrativa. Padova: Cedam, 1998.

SINISCALCO, Marco. Depenalizzazione e Garanzia. Dall'illecito Penale all'illecito Amministrativo: un Riesame Critico alla luce del Rapporto fra Potere e Cittadini. Bolonha: Mulino, 1995.

TOLEDO, Francisco de Assis. Princípios Básicos de Direito Penal. 5. ed. São Paulo: Saraiva, 2001.

TORRES, Ricardo Lobo. Curso de Direito Financeiro e Tributário. 9. ed. São Paulo: Renovar, 2002.

VILLEGAS, Hector. Direito Penal Tributário. São Paulo: Educ/Resenha Tributária, 1974.

VITTA, Heraldo Garcia. A Sanção no Direito Administrativo. São Paulo: Malheiros, 2003.

XAVIER, Alberto. VI Curso de Especialização em Direito Tributário (Notas Taquigráficas das Aulas e Debates). São Paulo: Resenha Tributária, 1978, v. II.

ZANOBINI, Guido. Le Sanzioni Amministrative. Torino: Fratelli Bocca, 1924.

Les Pouvoirs de l'Administration dans le Domain des Sanctions (Étude Adoptée par l'Assemblée Générale du Conseil d'État le 8 décembre 1994). Paris: La Documentation Française, 1995.

Informação bibliográfica deste texto, conforme a NBR 6023:2002 da Associação Brasileira de Normas Técnicas (ABNT):M

MELLO, Rafael Munhoz de. Sanção administrativa e o princípio da culpabilidade. AEC Revista de Direito Administrativo e Constitucional, Belo Horizonte, ano 5, n. 22, p. 25-57, out./dez. 2005.
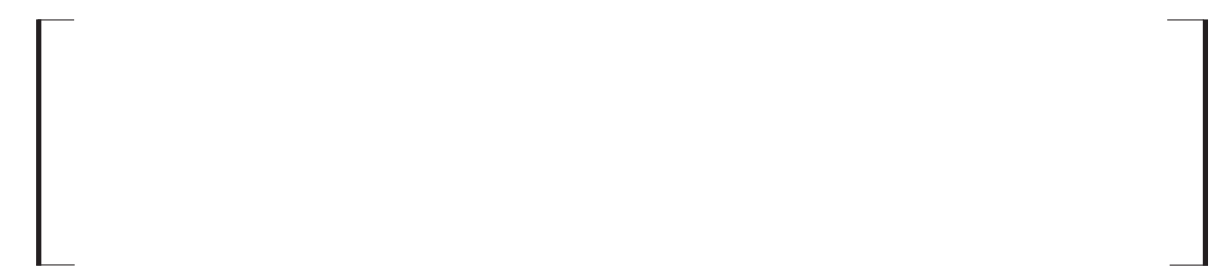

A \& C R. de Dir. Administrativo e Constitucional, Belo Horizonte, ano 5, n. 22, p. 25-57, out./dez. 2005 